\title{
Proposed minimal standards for describing new taxa of the family Flavobacteriaceae and emended description of the family
}

\footnotetext{
${ }^{1}$ Unité de Virologie et Immunologie Moléculaires, Institut National de la Recherche Agronomique, 78352 Jouy-en-Josas cedex, France

2 Institute for Fermentation, Osaka, Yodogawa-ku, Osaka 532-8686, Japan

${ }^{3}$ National Collection of Type Cultures, Central Public Health Laboratory, London NW9 5HT, UK
}

\author{
Jean-François Bernardet, ${ }^{1}$ Yasuyoshi Nakagawa ${ }^{2}$ and Barry Holmes, ${ }^{3}$ for \\ the Subcommittee on the taxonomy of Flavobacterium and Cytophaga- \\ like bacteria of the International Committee on Systematics of \\ Prokaryotes
}

\author{
Author for correspondence: Jean-François Bernardet. Tel: +33134652587. Fax: +33134652591. \\ e-mail: jfb@jouy.inra.fr
}

\begin{abstract}
In this paper minimal standards for the description of new genera and cultivable species in the family Flavobacteriaceae are proposed in accordance with Recommendation 30b of the Bacteriological Code (1990 Revision). In addition to specified phenotypic characteristics, the description of new species should be based on DNA-DNA hybridization data, and the placement of new taxa should be consistent with phylogenetic data derived from 165 rRNA sequencing. An emended description of the family is also proposed as several new taxa have been described since 1996. These proposals have been endorsed by the members of the Subcommittee on the taxonomy of Flavobacterium and Cytophaga-like bacteria of the International Committee on Systematics of Prokaryotes.
\end{abstract}

Keywords: minimal standards, Flavobacteriaceae

\section{INTRODUCTION}

Recommendation 30b of the Bacteriological Code (1990 Revision) (Lapage et al., 1992) calls for the development of minimal standards for describing new bacterial taxa. The aim of this paper is to propose minimal standards for descriptions of new genera and species of the family Flavobacteriaceae.

\section{Current taxonomy of the Flavobacteriaceae}

The family Flavobacteriaceae constitutes one of the main phyletic lines within the domain Bacteria together with the families Bacteroidaceae, Cytophagaceae, Sphingobacteriaceae and Spirosomaceae, as well as several taxa unaffiliated to any family (Woese et al., 1985; Bernardet et al., 1996). This line has been given several names, such as the 'flavobacter-bacteroides' phylum (Gherna \& Woese, 1992), the Flavobacterium-Cytophaga complex (Nakagawa \& Yamasato, 1993), rRNA superfamily V (Segers et al., 1993b), and

This article is dedicated to the memory of Jan Ursing, who contributed so much to the work of the subcommittee.

Published online ahead of print on 18 January 2002 as DOI 10.1099/ ijs.0.02136-0. the Cytophaga-Flavobacterium-Bacteroides group (Hirsch et al., 1998). Reichenbach (1992a) proposed that this phyletic line be equated with the order Cytophagales, although the position of the family Bacteroidaceae, which contains several genera of anaerobic bacteria (Holdeman et al., 1984), was not clear at that time. Since then, the family Bacteroidaceae has been unequivocally allocated to the phylum by several phylogenetic studies (Paster et al., 1994; Nakagawa \& Yamasato, 1996; Vandamme et al., 1996b; Hirsch et al., 1998), though it falls within the competence of the Subcommittee on the taxonomy of Gram-negative anaerobic rods. The family Sphingobacteriaceae, which is defined on firm genomic and phenotypic grounds (Steyn et al., 1998), encompasses closely related soil and clinical organisms. In contrast, phylogenetic studies (Bernardet et al., 1996; Nakagawa \& Yamasato, 1996) demonstrated that the distance between most of the organisms once included in the family Cytophagaceae solely on the basis of phenotypic characteristics (Reichenbach, 1989, 1992a) is actually considerable, hence a thorough emendation of this family is necessary. Similarly, the family Spirosomaceae (Larkin \& Borrall, 1984; Raj \& Maloy, 1990a) should probably be emended since the four genera it contains are only distantly related (Manz et al., 1996; Sly et al., 1998), 
Table 1. Currently recognized genera and species classified in the family Flavobacteriaceae

Names of type species are underlined. AL indicates that the species is cited on the Approved Lists of Bacterial Names (Skerman et al., 1980; Moore et al., 1985). Names in quotation marks have not been validly published. Previous names and corrected epithets are taken from Euzéby (1997). Accession number is that in the recognized culture collection in which the type strain was first deposited. ACAM, Australian Collection of Antarctic Microorganisms, University of Tasmania, Hobart, Tasmania, Australia; ATCC, American Type Culture Collection, Manassas, VA, USA; CCM, Czech Collection of Microorganisms, Brno, Czech Republic; CCUG, Culture Collection University of Göteborg, Göteborg, Sweden; DSM, Deutsche Sammlung von Mikroorganismen, Braunschweig, Germany; IAM, Institute of Applied Microbiology, University of Tokyo, Japan; IFO, Institute for Fermentation, Osaka, Japan; JCM, Japanese Collection of Microorganisms, Tokyo, Japan; LMG, Culture Collection of the Laboratorium voor Microbiologie, University of Ghent, Ghent, Belgium; NCIMB, National Collection of Industrial and Marine Bacteria, Aberdeen, UK; NCTC, National Collection of Type Cultures, London, UK; NIBHT, Culture Collection of the National Institute of Bioscience and Human Technology, Tsukuba, Japan.

\begin{tabular}{|c|c|c|c|c|}
\hline Genus and species* & Type strain & $\begin{array}{l}\mathrm{G}+\mathrm{C} \\
(\mathrm{mol} \%)\end{array}$ & Source & Reference(s) \\
\hline Genus Bergeyella & & & & Vandamme et al. (1994a) \\
\hline Bergeyella zoohelcum $^{a}$ & NCTC 11660 & 35 & Human sputum, USA & Holmes et al. (1986b) \\
\hline Genus Capnocytophaga & & & & Leadbetter et al. (1979); Holt \& Kinder (1989) \\
\hline Capnocytophaga canimorsus & ATCC 35979 & 37 & Human blood after dog bite, USA & Brenner et al. (1989); Vandamme et al. (1996b) \\
\hline Capnocytophaga cynodegmi & ATCC 49044 & 36 & Dog's mouth, USA, 1979 & Brenner et al. (1989); Vandamme et al. (1996b) \\
\hline Capnocytophaga gingivalis $^{\mathrm{AL}}$ & ATCC 33624 & 40 & Periodontitis in human, USA, 1978 & Leadbetter et al. (1979); Vandamme et al. (1996b) \\
\hline Capnocytophaga granulosa & JCM 8566 & 42 & Human dental plaque, Japan & Yamamoto et al. (1994); Vandamme et al. (1996b) \\
\hline Capnocytophaga haemolytica & JCM 8565 & 44 & Human dental plaque, Japan & Yamamoto et al. (1994); Vandamme et al. (1996b) \\
\hline Capnocytophaga ochracea ${ }^{\mathrm{AL}}$ & ATCC 27872 & 39 & Human oral cavity & Leadbetter et al. (1979); Vandamme et al. (1996b) \\
\hline$\overline{\text { Capnocytophaga sputigena }^{\mathrm{AL}}}$ & ATCC 33612 & 38 & Periodontitis in human, USA, 1978 & Leadbetter et al. (1979); Vandamme et al. (1996b) \\
\hline Genus Cellulophaga & & & & Johansen et al. (1999) \\
\hline Cellulophaga algicola & ACAM 630 & 37 & Surface of marine alga, Antarctica & Bowman (2000) \\
\hline Cellulophaga baltica & LMG 18535 & 33 & Surface of marine alga, Svaneke, Denmark & Johansen et al. (1999) \\
\hline Cellulophaga fucicola & LMG 18536 & 32 & Surface of marine alga, Hirsholm, Denmark & Johansen et al. (1999) \\
\hline Cellulophaga lytica $^{\mathrm{AL}, b}$ & ATCC 23178 & 33 & Beach mud, Limon, Costa Rica & $\begin{array}{l}\text { Lewin (1969); Reichenbach (1989); } \\
\quad \text { Johansen } \text { et al. (1999) }\end{array}$ \\
\hline Cellulophaga uliginosa ${ }^{c}$ & ATCC 14397 & 42 & Marine sediment & $\begin{array}{l}\text { ZoBell \& Upham (1944); Reichenbach (1989); } \\
\text { Bowman (2000) }\end{array}$ \\
\hline Genus Chryseobacterium & & & & Holmes et al. (1984a); Vandamme et al. (1994a) \\
\hline Chryseobacterium balustinum $^{\mathrm{AL}, d}$ & NCTC 11212 & 33 & Blood of freshwater fish, France, 1959 & Holmes et al. (1984a) \\
\hline Chrvseobacterium gleum $^{\mathrm{AL}, e}$ & ATCC 35910 & 37 & Human vaginal swab, UK, 1979 & Holmes et al. (1984b) \\
\hline Chryseobacterium indologenes ${ }^{\mathrm{AL}, f}$ & NCTC 10796 & 38 & Human trachea at autopsy, 1958 & Yabuuchi et al. (1983) \\
\hline Chryseobacterium indoltheticum ${ }^{\mathrm{AL}, g}$ & ATCC 27950 & 34 & Marine mud & Campbell \& Williams (1951) \\
\hline 'Chryseobacterium joostei' & LMG 18212 & 37 & Raw cow's milk, South Africa, 1981 & Hugo (1997) \\
\hline Chryseobacterium meningosepticum $^{\mathrm{AL}, h}$ & ATCC 13253 & 37 & Human cerebrospinal fluid, USA, 1949 & King (1959); Holmes et al. (1984a) \\
\hline 'Chryseobacterium proteolyticum' & NIBHT P17664 & 37 & Soil, rice field, Tsukuba, Japan & Yamaguchi \& Yokoe $(2000)$ \\
\hline Chryseobacterium scophthalmum $^{i}$ & CCM 4109 & 34 & Gills of marine fish, UK, 1987 & Mudarris et al. (1994) \\
\hline Genus Coenonia & & & & Vandamme et al. (1999) \\
\hline Coenonia anatina & LMG 14382 & 35 & Peking duck, Germany, 1991 & Vandamme et al. (1999) \\
\hline Genus Empedobacter & & & & Vandamme et al. (1994a) \\
\hline Empedobacter brevis $^{\mathrm{AL}, j}$ & NCTC 11099 & 33 & $\begin{array}{l}\text { Human bronchial secretion, Switzerland, } \\
1976\end{array}$ & Holmes et al. (1978); Holmes et al. (1984a) \\
\hline Genus Flavobacterium & & & & Bernardet et al. (1996) \\
\hline Flavobacterium aquatile $^{\mathrm{AL}, k}$ & ATCC 11947 & 33 & Deep well, UK & Holmes et al. (1984a); Bernardet et al. (1996) \\
\hline Flavobacterium branchiophilum ${ }^{l}$ & ATCC 35035 & 34 & Gills of salmon, Japan, 1977 & Wakabayashi et al. (1989); Bernardet et al. (1996) \\
\hline Flavobacterium columnare $^{m}$ & NCIMB 2248 & 32 & Kidney of salmon, USA, 1955 & $\begin{array}{l}\text { Bernardet \& Grimont (1989); } \\
\quad \text { Bernardet et al. (1996) }\end{array}$ \\
\hline Flavobacterium flevense $^{\mathrm{AL}, n}$ & ATCC 27944 & 35 & Freshwater lake, The Netherlands & $\begin{array}{l}\text { van der Meulen } \text { et al. (1974); } \\
\quad \text { Bernardet et al. (1996) }\end{array}$ \\
\hline Flavobacterium gillisiae & ACAM 601 & 32 & Sea ice, Prydz Bay, Antarctica & McCammon \& Bowman (2000) \\
\hline Flavobacterium hibernum $^{\circ}$ & ACAM 376 & 34 & Freshwater lake, Antarctica & McCammon et al. (1998) \\
\hline Flavobacterium hydatis $^{\mathrm{AL}, p}$ & ATCC 29551 & 34 & Gills of salmon, USA, 1974 & Strohl \& Tait (1978); Bernardet et al. (1996) \\
\hline Flavobacterium johnsoniae $^{\mathrm{AL}, q}$ & ATCC 17061 & 35 & Soil or mud, UK & Reichenbach (1989); Bernardet et al. (1996) \\
\hline Flavobacterium pectinovorum ${ }^{r}$ & NCIMB 9059 & 35 & Soil, UK & Reichenbach (1989); Bernardet et al. (1996) \\
\hline Flavobacterium psychrophilum ${ }^{s}$ & NCIMB 1947 & 33 & Kidney of salmon, USA & $\begin{array}{l}\text { Bernardet \& Grimont (1989); } \\
\quad \text { Bernardet } \text { et al. }(1996)\end{array}$ \\
\hline Flavobacterium saccharophilum ${ }^{t}$ & NCIMB 2072 & 36 & River Wey, UK, 1976 & $\begin{array}{l}\text { Agbo \& Moss (1979); Reichenbach (1989); } \\
\quad \text { Bernardet } \text { et al. (1996) }\end{array}$ \\
\hline Flavobacterium succinicans ${ }^{u}$ & DSM 4002 & 37 & Fin of salmon, USA, 1954 & $\begin{array}{l}\text { Anderson \& Ordal (1961); Reichenbach (1989); } \\
\quad \text { Bernardet et al. (1996) }\end{array}$ \\
\hline Flavobacterium tegetincola & ACAM 602 & 34 & $\begin{array}{l}\text { Cyanobacterial mat, marine salinity lake, } \\
\text { Antarctica }\end{array}$ & McCammon \& Bowman (2000) \\
\hline Flavobacterium xanthum ${ }^{v}$ & IAM 12026 & 36 & Soil, Showa station, Antarctica, 1967 & $\begin{array}{l}\text { Inoue \& Komagata (1976); Reichenbach (1989); } \\
\text { McCammon \& Bowman (2000) }\end{array}$ \\
\hline Genus Gelidibacter & & & & Bowman et al. (1997) \\
\hline Gelidibacter algens & ACAM 536 & 36 & Sea ice, Antarctica & Bowman et al. (1997) \\
\hline
\end{tabular}


Table 1 (cont.)

\begin{tabular}{|c|c|c|c|c|}
\hline Genus and species* & Type strain & $\begin{array}{l}\mathrm{G}+\mathrm{C} \\
(\mathrm{mol} \%)\end{array}$ & Source & Reference(s) \\
\hline Genus Myroides & & & & Vancanneyt et al. (1996) \\
\hline Myroides odoratus $^{\mathrm{AL}, w}$ & ATCC 4651 & 36 & Unknown & $\begin{array}{l}\text { Holmes et al. }(1977,1984 \mathrm{a}) \\
\quad \text { Vancanneyt } \text { et al. }(1996)\end{array}$ \\
\hline Myroides odoratimimus & NCTC 11180 & 32 & Human wound, UK & Vancanneyt et al. (1996) \\
\hline $\begin{array}{l}\text { Genus Ornithobacterium } \\
\text { Ornithobacterium rhinotracheale }\end{array}$ & CCUG 23171 & 38 & Respiratory tract of turkey, UK & $\begin{array}{l}\text { Vandamme et al. }(1994 \mathrm{~b}) \\
\text { Vandamme } \text { et al. }(1994 \mathrm{~b})\end{array}$ \\
\hline Genus Polaribacter & & & & Gosink et al. (1998) \\
\hline Polaribacter filamentus & ATCC 700397 & 32 & Surface sea water, Alaska, 1992 & Gosink et al. (1998) \\
\hline$\overline{\text { Polaribacter franzmannii }}$ & ATCC 700399 & 32 & Sea ice, Antarctica, 1992 & Gosink et al. (1998) \\
\hline Polaribacter glomeratus $^{x}$ & ACAM 171 & 33 & Marine salinity lake, Antarctica, 1984 & McGuire et al. (1987); Gosink et al. (1998) \\
\hline Polaribacter irgensii ${ }^{y}$ & ATCC 700398 & 31 & Sea water, Antarctica, 1986 & Gosink et al. (1998) \\
\hline Genus Psychroflexus & & & & Bowman et al. (1998) \\
\hline Psychroflexus gondwanensis $^{z}$ & ACAM 44 & 39 & Hypersaline lake, Antarctica, 1986 & Dobson et al. (1993); Bowman et al. (1998) \\
\hline Psychroflexus torquis & ACAM 623 & 33 & Sea ice, Antarctica & Bowman et al. (1998) \\
\hline Genus Psychroserpens & & & & Bowman et al. (1997) \\
\hline Psychroserpens burtonensis & ACAM 188 & 28 & Marine salinity lake, Antarctica & Bowman et al. (1997) \\
\hline Genus Riemerella & & & & Segers et al. (1993a) \\
\hline Riemerella anatipestifer $^{\mathrm{AL}, \alpha \alpha}$ & ATCC 11845 & 35 & Duck's blood, USA & Segers et al. (1993a) \\
\hline$\overline{\text { Riemerella columbina }}$ & LMG 11607 & 36 & Pigeon palatine cleft, Germany, 1989 & Vancanneyt et al. (1999) \\
\hline Genus Salegentibacter & & & & $\begin{array}{l}\text { McCammon \& } \\
\text { Bowman }(2000)\end{array}$ \\
\hline$\underline{\text { Salegentibacter salegens }}^{b b}$ & ACAM 48 & 37 & Water, Organic Lake, Antarctica, 1986 & $\begin{array}{l}\text { Dobson et al. (1993); McCammon } \\
\quad \text { \& Bowman }(2000)\end{array}$ \\
\hline Genus Tenacibaculum & & & & Suzuki et al. (2001) \\
\hline Tenacibaculum amylolyticum & IFO 16310 & 31 & Marine alga, Palau, Philippines & Suzuki et al. (2001) \\
\hline Tenacibaculum maritimum $^{c c}$ & ATCC 43398 & 32 & Diseased marine fish, Japan, 1977 & $\begin{array}{l}\text { Wakabayashi et al. (1986); Bernardet \& } \\
\text { Grimont (1989); Suzuki et al. (2001) }\end{array}$ \\
\hline Tenacibaculum mesophilum & IFO 16307 & 32 & Marine sponge, Numazu, Japan & Suzuki et al. (2001) \\
\hline Tenacibaculum ovolyticum $^{d d}$ & ATCC 51887 & 30 & Marine fish egg, Norway, 1989 & Hansen et al. (1992); Suzuki et al. (2001) \\
\hline Genus Weeksella & & & & Holmes et al. (1986a) \\
\hline$\underline{\text { Weeksella virosa }}$ & NCTC 11634 & 37 & Human urine, USA & Holmes et al. (1986a) \\
\hline Genus Zobellia & & & & Barbeyron et al. (2001) \\
\hline Zobellia galactanivorans ${ }^{e e}$ & DSM 12802 & 43 & Red marine alga, Brittany, France & Barbeyron et al. (2001) \\
\hline Zobellia uliginosa ${ }^{e}$ & ATCC 14397 & 42 & Marine sediment & $\begin{array}{l}\text { ZoBell \& Upham (1944); Reichenbach (1989); } \\
\quad \text { Barbeyron et al. (2001) }\end{array}$ \\
\hline Unaffiliated taxa & & & & Bernardet et al. (1996); Hanzawa et al. (1995) \\
\hline [Cytophaga] latercula & ATCC 23177 & 32 & $\begin{array}{l}\text { Seawater aquarium outflow, La Jolla, } \\
\text { USA }\end{array}$ & Lewin (1969); Reichenbach (1989) \\
\hline [Cytophaga] marinoflava & NCIMB 397 & 37 & Sea water, UK & Colwell et al. (1966); Reichenbach (1989) \\
\hline
\end{tabular}

* Previous names: $a$, [Weeksella] zoohelcum Holmes et al. 1986b; b, [Cytophaga] lytica Lewin 1969; c, [Flavobacterium] uliginosum ZoBell and Upham 1944, Weeks 1974, 'Agarbacterium uliginosum' Breed 1957a, [Cytophaga] uliginosa Reichenbach 1989 [this taxon has successively been reclassified in the genus Cellulophaga (Bowman, 2000) and in the genus Zobellia (Barbeyron et al., 2001); hence, it is provisionally listed within both genera in this table]; $d$, [Flavobacterium] balustinum Harrison 1929; e, [Flavobacterium] gleum Holmes et al. 1984b; $f$, [Flavobacterium] indologenes Yabuuchi et al. 1983; g, [Flavobacterium] indoltheticum Campbell and Williams 1951, 'Beneckea indolthetica' Campbell 1957; h [Flavobacterium] meningosepticum King 1959; $i$, 'Cytophaga scophthalmis', name as listed in 1989 in the catalogue of strains of the Czech Collection of Microorganisms, [Flavobacterium] scophthalmum Mudarris et al. 1994; j, '[Bacillus] brevis' Lustig 1890, 'Bacterium breve' Chester 1901, '[Flavobacterium] brevis' Bergey et al. 1923, 'Pseudobacterium brevis' Krasil'nikov 1949, 'Empedobacter breve' Prévot 1961, [Flavobacterium] breve Holmes and Owen 1982; $k$, '[Bacillus] aquatilis' Frankland and Frankland 1889, 'Bacterium aquatilis' Chester 1897, '[Flavobacterium] aquatilis' Bergey et al. 1923, '[Chromobacterium] aquatilis' Topley and Wilson 1929, '[Empedobacter] aquatile' Brisou et al. 1960; l, Flavobacterium branchiophila Wakabayashi et al. 1989; m, '[Bacillus] columnaris' Davis 1922, '[Chondrococcus] columnaris' Ordal and Rucker 1944, [Cytophaga] columnaris Garnjobst 1945, Reichenbach 1989, [Flexibacter] columnaris Leadbetter 1974, Bernardet and Grimont 1989; n, [Cytophaga] flevensis van der Meulen et al. 1974, Reichenbach 1989; o, 'Flavobacterium ameridies', name as deposited in the 16S rRNA sequence databases; $p$, [Cytophaga] aquatilis Strohl and Tait 1978; q, [Cytophaga] johnsonae Stanier 1947, Reichenbach 1989, '[Cytophaga] johnsonii' Stanier 1957; r, 'Flavobacterium pectinovorum' Dorey 1959, '[Empedobacter] pectinovorum' Kaiser 1961, [Cytophaga] pectinovora Reichenbach 1989; s, [Cytophaga] psychrophila Borg 1960, Reichenbach 1989, [Flexibacter] psychrophilus Bernardet and Grimont 1989; $t$, [Cytophaga] saccharophila Agbo and Moss 1979; $u$, [Cytophaga] succinicans Anderson and Ordal 1961, Reichenbach 1989, '[Flexibacter] succinicans' Leadbetter 1974; v, '[Cytophaga] xantha' Inoue and Komagata 1976; w, '[Flavobacterium] odoratum' Stutzer in Stutzer and Kwaschnina 1929; x, [Flectobacillus] glomeratus McGuirre et al. 1987; y, 'Antarcticum vesiculatum', 'Vesiculatum antarctica', names as deposited in the databases of $16 \mathrm{~S}$ rRNA sequences; $z$, [Flavobacterium] gondwanense Dobson et al. 1993, Psychroflexus gondwanense Bowman et al. 1998; the original spelling of the specific epithet was corrected on validation (Bowman et al., 1999); aa, 'Pfeifferella anatipestifer' Hendrickson and Hilbert 1932, [Moraxella] anatipestifer Bruner and Fabricant 1954, [Pasteurella] anatipestifer Breed 1957b; bb, [Flavobacterium] salegens Dobson et al. 1993; cc, '[Flexibacter] marinus' Hikida et al. 1979, [Flexibacter] maritimus Wakabayashi et al. 1986, [Cytophaga] marina Reichenbach 1989; dd, [Flexibacter] ovolyticus Hansen et al. 1992; ee, '[Cytophaga] drobachiensis' Potin et al. 1991, Zobellia galactanovorans Barbeyron et al. 2001; the original spelling of the specific epithet was corrected on notification (International Journal of Systematic Bacteriology, 2001). 
although they do share some 16S rRNA sequence signatures (Woese et al., 1990a). The CytophagaFlavobacterium-Bacteroides phylum also comprises several other genera and species which are phylogenetically distant (Manz et al., 1996; Nakagawa \& Yamasato, 1996); difficulties will probably arise in delineating new families for some of these taxa, most of which are poorly described and only represented by single strains.

The family Flavobacteriaceae was proposed by Jooste (1985) and included in the first edition of the Bergey's Manual of Systematic Bacteriology (see Reichenbach, 1989), but the taxon was not formally described (Holmes, 1997). The name of the family was subsequently validated (Reichenbach, 1992b) and an emended description was published (Bernardet et al., 1996). The family included Flavobacterium (Bernardet et al., 1996), the type genus, and the genera Bergeyella (Holmes et al., 1986b; Vandamme et al., 1994a), Capnocytophaga (Holt \& Kinder, 1989; Vandamme et al., 1996b), Chryseobacterium (Holmes et al., 1984a; Vandamme et al., 1994a), Empedobacter (Holmes et al., 1978; Vandamme et al., 1994a), Ornithobacterium (Vandamme et al., 1994b), Riemerella (Segers et al., 1993a; Vancanneyt et al., 1999) and Weeksella (Holmes et al., 1986a). Another taxon included in the family, [Flavobacterium] odoratum (brackets indicate generically misclassified bacteria) (Holmes et al., 1977), was subsequently transferred to the new genus $M y$ roides (Vancanneyt et al., 1996); a second Myroides species was also described. Several new species have been added to the family Flavobacteriaceae since 1996, namely Flavobacterium hibernum (McCammon et al., 1998); Flavobacterium gillisiae, Flavobacterium tegetincola and Flavobacterium xanthum (previously '[Cytophaga] xantha') (McCammon \& Bowman, 2000); Riemerella columbina (Vancanneyt et al., 1999); 'Chryseobacterium joostei' (Hugo, 1997); and 'Chryseobacterium proteolyticum' (Yamaguchi \& Yokoe, 2000). The new genus Coenonia has also been assigned to the taxon (Vandamme et al., 1999).

The family Flavobacteriaceae also includes a rather complex group of halophilic organisms, many of which are psychrophilic. The structure of this group has been progressively unravelled following the emended description of the family (Bernardet et al., 1996). Five new genera of polar organisms have been described, namely the monospecific genera Gelidibacter and Psychroserpens (Bowman et al., 1997), Polaribacter (with four species, one of which was previously called [Flectobacillus] glomeratus) (Gosink et al., 1998), Psychroflexus (with two species, one of which was previously called [Flavobacterium] gondwanense) (Bowman et al., 1998) and Salegentibacter (comprising the taxon previously called [Flavobacterium] salegens) (McCammon \& Bowman, 2000). The new genus Cellulophaga has been proposed for [Cytophaga] lytica and two new marine species (Johansen et al., 1999) (this genus was erroneously included in the family Cytophagaceae); a new Cellulophaga species has subse- quently been described and [Cytophaga] uliginosa has also been reclassified in this genus (Bowman, 2000). More recently, it has been proposed to reclassify [Cytophaga] uliginosa in the new genus Zobellia, together with a new species (Barbeyron et al., 2001). [Flexibacter] maritimus and [Flexibacter] ovolyticus are two phylogenetically close and well-defined species that are represented by several strains (Bernardet et al., 1996 ); the new genus Tenacibaculum has recently been proposed to classify these organisms and two new species (Suzuki et al., 2001). In contrast, [Cytophaga] latercula and [Cytophaga] marinoflava are phylogenetically distant from the other halophilic taxa and cannot be assigned to a single genus; they remain generically misclassified and probably constitute the core of new genera (Hanzawa et al., 1995; Bowman et al., 1997, 1998). These two organisms will not be considered in this paper, as minimal standards cannot accommodate such phylogenetically isolated and poorly described species represented by single strains (Colwell et al., 1966; Lewin, 1969; Reichenbach, 1989). Several poorly described algicidal and/or algal-lytic gliding bacteria have been allocated to the group of the halophilic Flavobacteriaceae (Hanzawa et al., 1995; Maeda et al., 1998; Kondo et al., 1999). This group is also well represented in mangrove environments (Nakagawa et al., 2001).

A list of the currently recognized taxa classified in the family Flavobacteriaceae, namely the 18 well-defined genera and the two unaffiliated organisms, is shown in Table 1. The position of the family Flavobacteriaceae in the Cytophaga-Flavobacterium-Bacteroides phylum is shown in Fig. 1. The phylogenetic relationships of the taxa classified in the family Flavobacteriaceae are shown in Fig. 2. Although not included in the Tables and not further considered in this paper, invalid taxa belonging to the family Flavobacteriaceae for which $16 \mathrm{~S}$ rRNA sequence is available have been included in Fig. 2 for information; their names are given in quotation marks.

A rather surprising result from several phylogenetic investigations was the allocation to the family Flavobacteriaceae of several intracellular symbionts of insects. In addition to the long established genus Blattabacterium (Dasch et al., 1984), which encompasses organisms that live in the tissues of several cockroach species (Bandi et al., 1994), these organisms include various termite symbionts and ladybird beetle male-killing agents (Hurst et al., 1997, 1999). The sequences of the $16 \mathrm{~S}$ rRNA of these organisms are the only clue to their phylogenetic affiliation as they have yet to be isolated, cultivated and described. The symbiont group is unequivocally included in the family Flavobacteriaceae in some phylogenetic analyses (Manz et al., 1996; Bowman et al., 1998; Hirsch et al., 1998) while in others it branches slightly below the other members of the family (Bandi et al., 1994; Hurst et al., 1997, 1999; and the present study; see Fig. 1). Although the close relationship of these organisms with the family Flavobacteriaceae is established, little 
more can be said about them here as minimal standards cannot be applied to unculturable bacteria. The provisional category Candidatus (Murray \& Stackebrandt, 1995) has been included as an Appendix in the Bacteriological Code (1990 Revision) for such microorganisms (Labeda, 1997). Several intracellular bacteria isolated from amoebae have also been allocated to the family Flavobacteriaceae based on phenotypic characteristics and fatty acid profiles, but these potentially novel organisms have not been fully described (Müller et al., 1999, and references therein).

\section{General principles}

The primary aim of this paper is to provide bacteriologists involved in the taxonomy of the family Flavobacteriaceae with a framework for describing new taxa. The list of characters whose determination is strongly recommended in the following paragraphs may seem long and demanding but this should not discourage scientists from publishing the description of new species since minimal standards are only designed to avoid the publication of poorly characterized 'new' taxa. It is well known that such taxa are difficult to retract and can confuse bacterial nomenclature for decades. The general principles outlined here have already been mentioned in corresponding contributions dealing with other bacterial taxa (Graham et al., 1991; Vincent Lévy-Frébault \& Portaels, 1992; Ursing et al., 1994; International Committee on Systematic Bacteriology Subcommittee on the taxonomy of Mollicutes, 1995; Oren et al., 1997; Freney et al., 1999; Dewhirst et al., 2000).

A polyphasic approach to bacterial systematics has been progressively adopted by most bacteriologists over the last decade (Murray et al., 1990; Vandamme et al., 1996a). This approach integrates phenotypic and chemotaxonomic characterization with genomic and phylogenetic data. The description of new taxa in the family Flavobacteriaceae should thus rely on a wide variety of phenotypic and molecular properties in order to consider the greatest percentage of the bacterial genome possible. It is not possible to recommend a single medium that supports the growth of all members of the Flavobacteriaceae, hence it is suggested that the best growth medium and the optimal growth conditions be determined before strains are further investigated. When primary isolation is performed on environmental samples or external lesions of animals, bacterial cultures are frequently mixed; consequently, the purity of cultures should be checked by an accurate examination of agar plates under a stereomicroscope $(\times 20)$. All studies should be performed on actively growing cultures. As many isolates as possible of a candidate new taxon should be included, preferably representing a wide variety of independent sources (i.e. different animal hosts, geographical locations, environmental samples, years of isolation); these data should be specified in the article.
The clustering of strains by numerical taxonomic methods (Sneath \& Sokal, 1973) is highly recommended when a sufficient number of phenotypic properties is examined.

When a potentially new species is studied, the type strains of all related species should be included for comparison. In order to restrict the number of these species (and consequently the amount of technically demanding investigations, such as DNA-DNA hybridizations), the new species can first be located within the $16 \mathrm{~S}$ rRNA tree; this is straightforward given the extensive database now available for the family Flavobacteriaceae (Woese et al., 1990b; Gherna \& Woese, 1992; Nakagawa \& Yamasato, 1993, 1996; Dobson et al., 1993; Bandi et al., 1994; Vandamme et al., 1996b; Hurst et al., 1997; Bowman et al., 1997, 1998; Gosink et al., 1998; Maidak et al., 1999; Bowman, 2000; Suzuki et al., 2001). Such comparative studies should include as many related organisms as possible in order to improve the significance of the tree. Differences in $16 \mathrm{~S}$ rRNA sequences of up to $5 \%$ have been found among strains of some species classified in the family (Clayton et al., 1995; Triyanto \& Wakabayashi, 1999); hence comparison of sequences of several strains is desirable since this will improve the soundness of the phylogenetic hypotheses and provide an estimation of the genomic diversity of the new taxon.

It is very important that the methods of alignment and the treeing algorithms used in phylogenetic studies are stated. Phylogenetic trees should be constructed using more than two methods, e.g. choice from maximumlikelihood, maximum-parsimony, unweighted pairgroup method using arithmetic averages (UPGMA) or neighbour-joining (Sneath \& Sokal, 1973; Nei, 1987; Saitou \& Nei, 1987). In addition, the reliability of branchings should be statistically evaluated using a criterion of goodness such as a bootstrap analysis (Felsenstein, 1985). It is imperative that new $16 \mathrm{~S}$ rRNA sequences are deposited in a recognized database and that the accession numbers are included in the species description. In most databases, bacterial nomenclature is not always properly updated; hence new 16S rRNA sequences should preferably be deposited under the laboratory code or culture collection number of the isolate or, for instance, under such provisional denominations as 'Flavobacterium sp. no. X', 'strain no. Y' or 'fish isolate no. Z'. This practice will ensure that databases, publications and phylogenetic trees do not contain prematurely attributed invalid Latin names.

The sequence of molecules other than 16S rRNA may also provide interesting phylogenetic informations: Yamamoto \& Harayama (1996) have shown that a phylogenetic analysis based on the DNA gyrase B subunit gene $($ gyrB $)$ may have a greater degree of resolution than one based on the $16 \mathrm{~S}$ rRNA sequence because protein-encoding genes evolve faster than rRNA genes. However, the two techniques have 


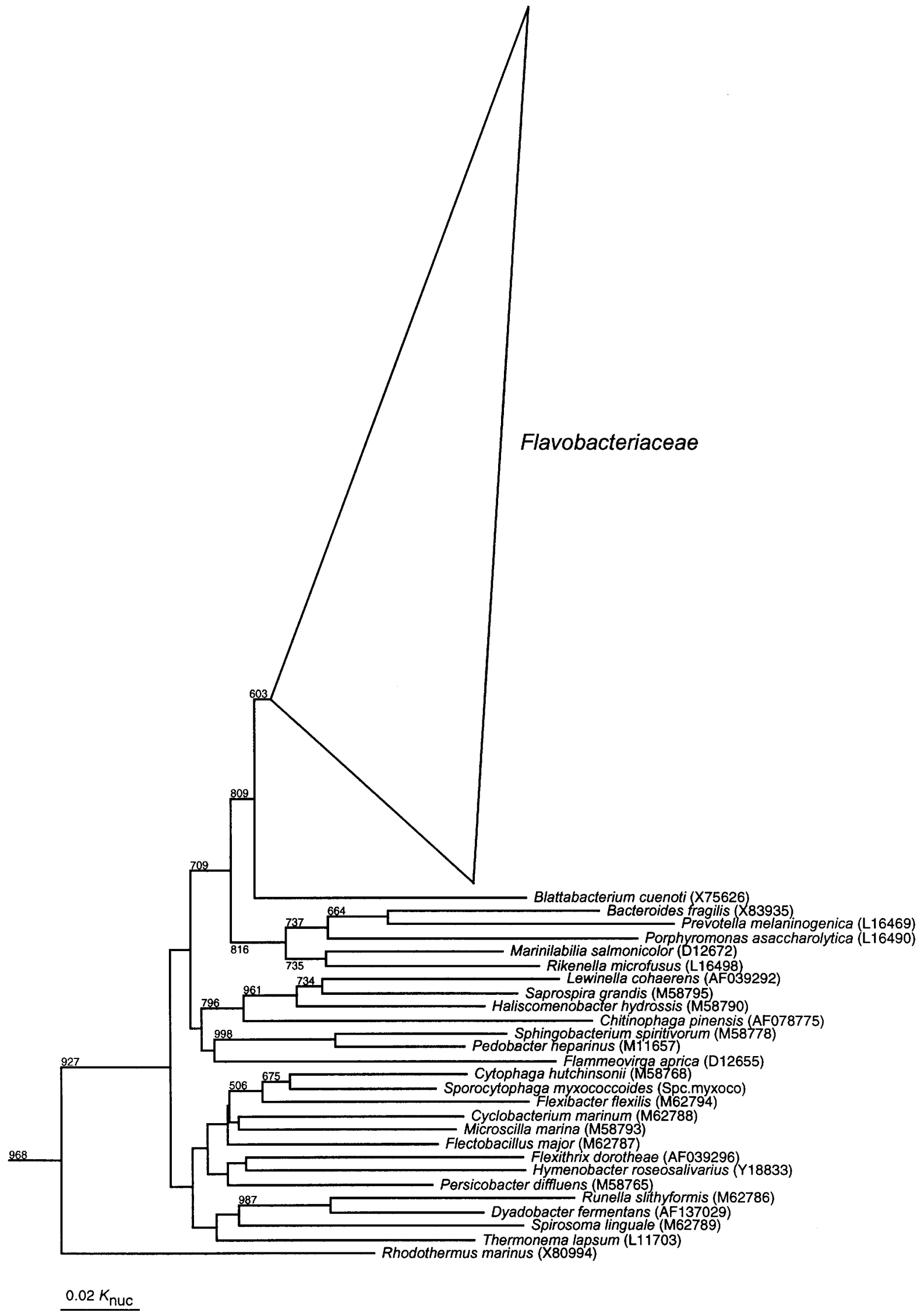

Fig. 1. For legend see facing page. 
recently been shown to generate almost equivalent phylogenetic structures for the Cytophaga-Flavobacterium-Bacteroides phylum (Suzuki et al., 2001).

New isolates, or at least a selection of representative strains, should be preserved in the laboratory by freezedrying, liquid drying, or by storage in liquid nitrogen or at $-80^{\circ} \mathrm{C}$; two methods should preferably be used. Several procedures for the preservation of members of the family Flavobacteriaceae have been described (Holmes et al., 1984a; Reichenbach, 1989, 1992a; Holmes, 1992; Ostland et al., 1994; Desolme \& Bernardet, 1996).

A type species must be designated when a new genus is described, and a type strain must be selected for every novel species. According to Recommendation 30a of the Bacteriological Code (1990 Revision) (Lapage et al., 1992), all type strains should be deposited in a recognized culture collection; this Recommendation has been revised (i) to require that this deposition occurs; (ii) and that it occurs before the validation of the new taxa (Labeda, 1997). It is now required that type strains be deposited in at least two different recognized culture collections, preferably not in the same country (Labeda, 2000). It is also good practice to deposit a few additional representative strains of the new taxon and to store duplicate sets of preserved strains in two separate locations. Additional changes have been proposed for the Rule governing the use of 'patent strains' as type strains (Tindall, 1999).

All taxonomic methods included in the description of new taxa should be given in detail or references to the appropriate publications in English should be given. It has been suggested that "phenotypic descriptions of strains of existing species used for comparisons to a proposed new species should be based on tests performed on those strains in the authors' own laboratories, rather than on published data, to assure comparability of results' (International Committee on Systematic Bacteriology, 1997). Discrepancies in the phenotypic properties of some species classified in the family Flavobacteriaceae have indeed been noticed when the same strains have been examined in different studies (denoted by ' $v$ ' in Table 2), probably because different methods were used. Commercially available galleries such as API ZYM (Yabuuchi et al., 1983; Holmes et al., 1984b; Bernardet \& Grimont, 1989;
Hansen et al., 1992; Mudarris et al., 1994; Vandamme et al., 1994b, 1999; Bernardet et al., 1996; Vancanneyt et al., 1996, 1999), API 50CH (Bernardet, 1989b; Bernardet \& Grimont, 1989); API 20E (McCammon et al., 1998), API 20NE (McCammon et al., 1998; Vancanneyt et al., 1996; Vancanneyt et al., 1999; Vandamme et al., 1999; J.-F. Bernardet, unpublished results), API ID 32E (Vancanneyt et al., 1999; Vandamme et al., 1999), Biotype 100 (Vancanneyt et al., 1996; J.-F. Bernardet, unpublished results) or Biolog GN MicroPlate (Vancanneyt et al., 1996; McCammon et al., 1998; Johansen et al., 1999) may be used. For instance, some Chryseobacterium species are included in the analytical profile index of API 20NE galleries and most strains are actually able to grow at the temperature recommended by the manufacturer (i.e. $30^{\circ} \mathrm{C}$ ). However, some other galleries have been devised for clinically significant organisms grown at $37^{\circ} \mathrm{C}$; hence results obtained with environmental, polar or fish isolates grown at lower temperatures must be carefully interpreted. Moreover, discrepancies may occur between the results of conventional tests and those of the corresponding tests included in galleries (see below).

The descriptions of new taxa should preferably be published in the International Journal of Systematic and Evolutionary Microbiology (IJSEM); when published in another journal, a reprint should be submitted to the IJSEM so that the new taxon can be rapidly included in one of the Validation Lists that appear periodically in that journal as required by the Bacteriological Code (1990 Revision) (Lapage et al., 1992; International Journal of Systematic Bacteriology, 1992). If the scientists proposing a new taxon are not familiar with bacterial nomenclature or with the use of Latin for naming scientific taxa, they are strongly advised to read the specialized literature (Bousfield, 1993; MacAdoo, 1993; Buchanan, 1994; Trüper, 1996) or refer to a Latin scholar.

Some of the taxa that have been assigned to the family Flavobacteriaceae contain organisms that are rather fastidious (e.g. some animal pathogens and some capnophilic organisms) or occur in low numbers in the environment (e.g. some aquatic organisms). The description of such bacteria may thus require some flexibility in the application of the general principles stated above, as well as in the recommended minimal

\begin{abstract}
Fig. 1. Phylogenetic position of the family Flavobacteriaceae in the Cytophaga-Flavobacterium-Bacteroides phylum based on 16S rRNA sequence comparisons using the neighbour-joining method (Saitou \& Nei, 1987). Sequences are taken from the DDBJ and GenBank nucleotide databases, apart from the sequence of Sporocytophaga myxococcoides which comes from the Ribosomal Database Project (Maidak et al., 1999). The type species of all validly described genera in the phylum are represented by the sequence of their type strain. Mitsuokella multacida could not be included because the comparison of the available 16S rRNA sequence did not result in its allocation to the phylum. Accession numbers for the sequences are given in parentheses. Scale bar, $0.02 K_{\text {nuc }}$ (Kimura, 1980). The numbers on the branches represent the confidence limits (expressed as percentages rounded up to whole numbers) estimated by a bootstrap analysis (Felsenstein, 1985) of 1000 replicates; confidence limits less than $50 \%$ are not shown. Sequences were aligned using the CLUSTAL W version 1.8 software package (Thompson et al., 1994). The alignments were modified manually against the $16 \mathrm{~S}$ rRNA secondary structure of Escherichia coli (Brosius et al., 1978). Positions at which the secondary structures varied in the strains (positions 66-104, 143-220, 447-487, 841-845, 991-1045, 1134-1140 and 1446-1456) and all sites which were not determined in any sequence were excluded from the analysis. The number of nucleotides compared was 831 bp. Agrobacterium tumefaciens, Bacillus subtilis and Escherichia coli were used as outgroups.
\end{abstract}




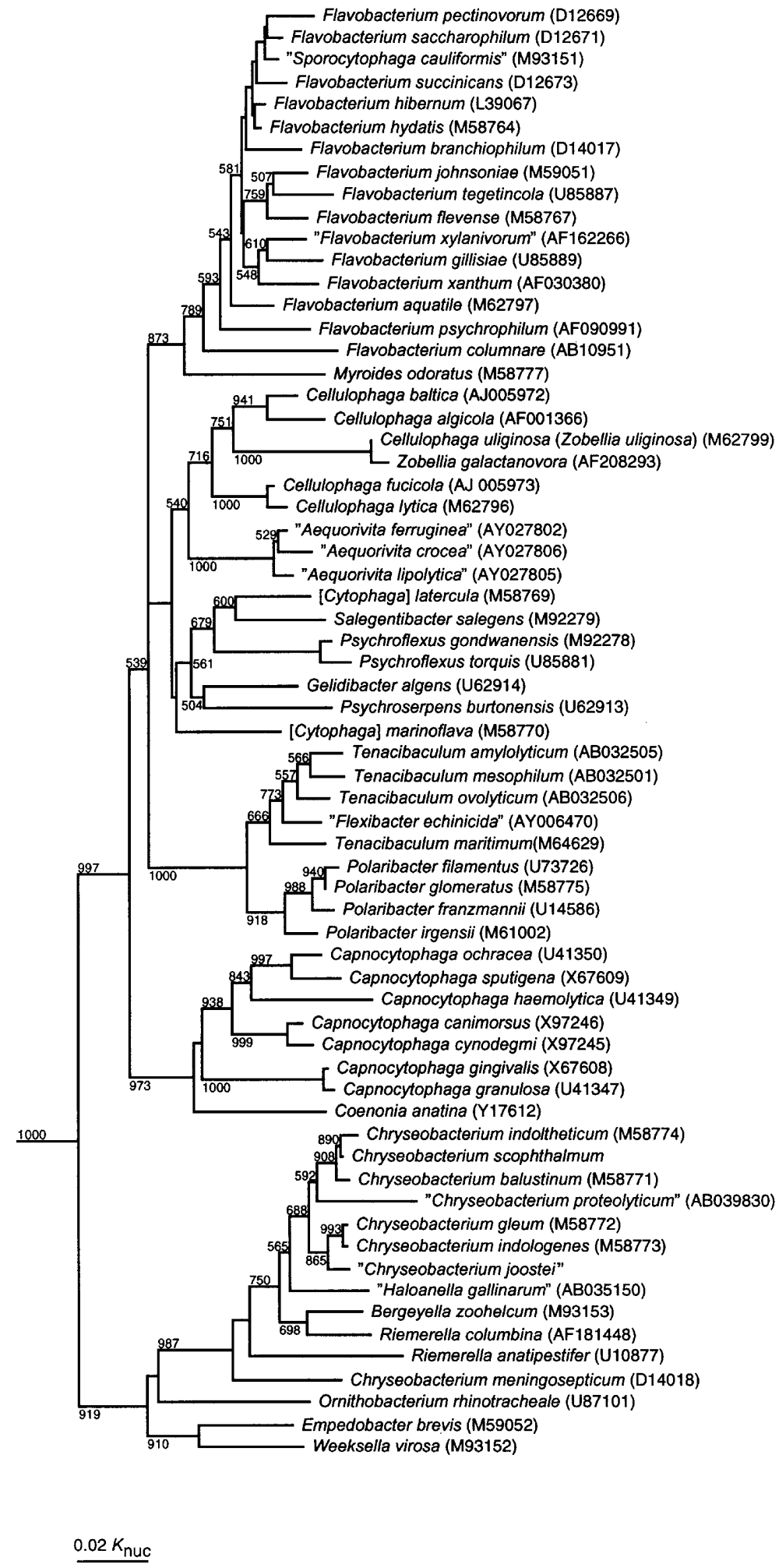

Fig. 2. Phylogenetic relationships among representatives of the family Flavobacteriaceae based on comparisons of 16S rRNA sequence. All species of Flavobacteriaceae are included (except Myroides odoratimimus for which no data are available) and represented by the sequence of their type strain (except Empedobacter brevis). Invalid taxa which $16 \mathrm{~S}$ rRNA sequence is available have also been included for information; their names are in quotation marks. The 165 rRNA sequences of Tenacibaculum species were obtained from Makoto Suzuki, and those of Chryseobacterium scophthalmum and 'Chryseobacterium joostei' from Paul Segers (personal communications). The number of nucleotides compared was $899 \mathrm{bp}$. Agrobacterium tumefaciens, Bacillus subtilis, and Escherichia coli were used as outgroups. Other details are given in the legend to Fig. 1.

features that should be included in descriptions of new taxa. The description of new taxa based on single strains is not encouraged as such taxa cannot take biological diversity into account; this in turn makes it difficult to decide whether some features are relevant to the description of the species or the genus. It is preferable to study at least two strains. However, when a single strain has been retrieved from an important source or has important biological properties, it does make sense to describe it as a new species though in such cases an extensive phenotypic, genomic and phylogenetic study should be undertaken to ensure 
that the organism differs significantly from members of all related species.

\section{General features of species classified in the family Flavobacteriaceae}

An emended description of the family Flavobacteriaceae is needed due to the changes outlined above. The modifications and additions resulting from nomenclatural changes and from the descriptions of several additional taxa since the first description of the family (Bernardet et al., 1996) are in bold.

\section{Emended description of the family Flavobacteriaceae Reichenbach 1989}

Cells are short to moderately long rods with parallel or slightly irregular sides and rounded or slightly tapered ends. They are usually $0.3-0.6 \mu \mathrm{m}$ wide and $1-10 \mu \mathrm{m}$ long, though members of some species may form filamentous flexible cells (e.g. Flavobacterium and Tenacibaculum) or coiled and helical cells (Polaribacter, Psychroflexus and Psychroserpens strains) under certain growth conditions; ring-shaped cells are not formed. Cells in old cultures may form spherical or coccoid bodies (e.g. Flavobacterium, Gelidibacter, Psychroserpens and Tenacibaculum). Gram-negative. Nonspore-forming. Gas vesicles are produced in members of some Polaribacter species. Flagellae are usually absent; the only Polaribacter irgensii strain available is flagellated, but motility has not been observed in wet mounts. Non-motile (Bergeyella, Chryseobacterium, Coenonia, Empedobacter, Myroides, Ornithobacterium, Polaribacter, Psychroserpens, Riemerella, Salegentibacter and Weeksella strains, and Psychroflexus gondwanensis strains) or motile by gliding (Capnocytophaga, Cellulophaga, Gelidibacter, Flavobacterium, Tenacibaculum and Zobellia strains, and Psychroflexus torquis strains).

Growth is aerobic (Bergeyella, Cellulophaga, Chryseobacterium, Empedobacter, Flavobacterium, Gelidibacter, Myroides, Polaribacter, Psychroflexus, Psychroserpens, Salegentibacter, Tenacibaculum, Weeksella and Zobellia strains) or microaerobic to anaerobic (Capnocytophaga, Coenonia, Ornithobacterium and Riemerella strains). The optimum temperature is usually in the range $25-35^{\circ} \mathrm{C}$, but members of some species or genera are psychrophilic or psychrotolerant (Flavobacterium psychrophilum and the Antarctic Flavobacterium species, as well as Gelidibacter, Polaribacter, Psychroflexus, Psychroserpens and Salegentibacter strains). Members of some taxa are halophilic to varying degrees (Cellulophaga, Gelidibacter, Polaribacter, Psychroflexus, Psychroserpens, Salegentibacter, Tenacibaculum and Zobellia strains).

Colonies are non-pigmented (Bergeyella, Coenonia, Ornithobacterium and Weeksella strains) or pigmented by carotenoid or flexirubin pigments or both (Capnocytophaga, Cellulophaga, Chryseobacterium, Empedobacter, Flavobacterium, Gelidibacter, My- roides, Polaribacter, Psychroflexus, Psychroserpens, Riemerella, Salegentibacter, Tenacibaculum and Zobellia strains).

Menaquinone 6 is either the only respiratory quinone or the major respiratory quinone. Chemo-organotrophic. Intracellular granules of poly- $\beta$-hydroxybutyrate are absent. Sphingophospholipids are absent. Homospermidine is the major polyamine though agmatine, cadaverine and putrescine are frequently present as minor components. Crystalline cellulose (i.e. filter paper) is not decomposed. The DNA base composition ranges from 27 to $44 \mathrm{~mol} \% \mathrm{G}+\mathrm{C}$.

Mostly saprophytic in terrestrial and aquatic habitats. Several members of the family are commonly isolated from diseased humans or animals, some species are considered true pathogens. The type genus is Flavobacterium Bergey, Harrison, Breed, Hammer and Huntoon 1923, as emended in 1996 (Bernardet et al., 1996).

Other taxa included in the family Flavobacteriaceae are the genera Bergeyella, Capnocytophaga, Cellulophaga, Chryseobacterium, Coenonia, Empedobacter, Gelidibacter, Myroides, Ornithobacterium, Polaribacter, Psychroflexus, Psychroserpens, Riemerella, Salegentibacter, Tenacibaculum, Weeksella and Zobellia. Several species unaffiliated to any genus also belong to the family. Several intracellular symbionts of insects and intracellular parasites of amoebae are closely related to the family.

Among the properties listed above, some may be considered particularly important because they allow a clear differentiation between members of the family Flavobacteriaceae and those of other families in the Cytophaga-Flavobacterium-Bacteroides phylum. These properties should be investigated if the necessary equipment and knowledge are available (Suzuki et al., 1993). The presence of sphingophospholipids, for instance, characterizes members of the family Sphingobacteriaceae. In addition, all current members of the family Flavobacteriaceae exhibit menaquinone 6 as their only or major respiratory quinone (Bernardet et al., 1996), whereas menaquinone 7 is present in members of all related families and taxa that have been tested (Hanzawa et al., 1995).

Some species in the family Flavobacteriaceae degrade soluble cellulose derivatives such as carboxymethylcellulose or hydroxyethylcellulose but, since these compounds may be degraded by enzymes other than cellulases, this does not demonstrate that these species are cellulolytic. The decomposition of crystalline cellulose (i.e. filter paper) requires the production of a specific cellulase, hence only strains able to degrade filter paper should be regarded as cellulose degraders (Reichenbach, 1989). The inability to degrade crystalline cellulose has been confirmed in members of most taxa included in the family Flavobacteriaceae (Bernardet, 1989a; Reichenbach, 1989, 1992a; J.-F. Bernardet, unpublished) including members of the 
Table 2. Differential characteristics of taxa classified in the family Flavobacteriaceae

Bergeyella zoohelcum; 2, Capnocytophaga; 3, Cellulophaga; 4, Chryseobacterium; 5, Coenonia anatina; 6, Empedobacter brevis; 7, Flavobacterium; 8, Gelidibacter algens; 9 , Myroides; 10, Ornithobacterium rhinotracheale; 11, Polaribacter; 12, Psychroflexus; 13, Psychroserpens burtonensis; 14, Riemerella; 15, Salegentibacter; 16, Tenacibaculum; 17, Weeksella virosa; 18, Zobellia. Habitat: P, parasitic; S, saprophytic; FL, free-living; (me), marine environment. Data taken from Barbeyron et al. (2001), Bernardet

(1989a), Bernardet \& Grimont (1989), J.-F. Bernardet (unpublished results), Bowman et al. (1997, 1998), Bowman (2000), J. P. Bowman (personal communication), Bruun \& Ursing (1987), Dees et al. (1986), Dobson et al. (1993), Gosink et al. (1998), Hansen et al. (1992), Holmes (1992), Holmes et al. (1977, 1978, 1984a, 1986a, 1986b), Hugo (1997), Johansen et al. (1999), Lewin \& Lounsbery (1969), London et al. (1985), McCammon \& Bowman (2000), McGuire et al. (1987), Ostland et al. (1994), Oyaizu \& Komagata (1981), Reichenbach (1989), Segers et al. (1993a), Suzuki et al. (2001), Ursing \& Bruun (1991), Vancanneyt et al. (1999), Vandamme et al. (1994a, 1994b, 1999), Yabuuchi et al. (1983), Yamaguchi \& Yokoe (2000) and Yamamoto et al. (1994). Additional phenotypic characteristics that differentiate (a) the Capnocytophaga species, Coenonia anatina, Ornithobacterium rhinotracheale and Riemerella anatipestifer are described in Vandamme et al. (1994b, 1999), (b) the genera Cellulophaga, Gelidibacter, Polaribacter, Psychroflexus, Psychroserpens, Salegentibacter, Tenacibaculum, Zobellia, and other related halophilic organisms are described in Bowman et al. (1997, 1998), Gosink et al. (1998), Johansen et al. (1999), McCammon \& Bowman (2000), Barbeyron et al. (2001) and Suzuki et al. (2001), (c) the genera Bergeyella, Chryseobacterium, Empedobacter, Flavobacterium, Myroides and Weeksella are described in Bernardet et al. (1996). [Cytophaga] latercula and [Cytophaga] marinoflava are not included in this table; their phenotypic characteristics are described by Lewin (1969) and Colwell et al. (1966), respectively, as well as by Reichenbach (1989), Dobson et al. (1993) and Bernardet et al. (1996). +, Positive reaction; -, negative reaction; (+), weak positive reaction; v, varies within and/or between species; $\underline{v}$, varies between references; ND, not determined or determined for some species only. The type of yellow pigment (when determined) is indicated by a F (flexirubin-type pigment) or a C (carotenoid type pigment). A greyish-white to beige pigment is produced by Riemerella anatina strains on some solid media.

\begin{tabular}{|c|c|c|c|c|c|c|c|c|c|c|c|c|c|c|c|c|c|c|}
\hline & 1 & 2 & 3 & 4 & 5 & 6 & 7 & 8 & 9 & 10 & 11 & 12 & 13 & 14 & 15 & 16 & 17 & 18 \\
\hline Habitat & $\mathrm{P}$ or $\mathrm{S}$ & $\mathrm{P}$ or $\mathrm{S}$ & $\begin{array}{c}\mathrm{FL}(\mathrm{me}) \text { or } \\
\mathrm{S}\end{array}$ & $\mathrm{FL}, \mathrm{S}$ or $\mathrm{P}$ & $\mathrm{P}$ & $\begin{array}{c}\text { FL or } \\
\mathrm{S}\end{array}$ & FL or $\mathrm{S}$ & $\begin{array}{l}\mathrm{FL}(\mathrm{me}) \\
\text { or } \mathrm{S}\end{array}$ & $\begin{array}{c}\text { FL or } \\
\text { S }\end{array}$ & $\mathrm{P}$ & $\begin{array}{c}\text { FL } \\
\text { (me) } \\
\text { or S }\end{array}$ & $\begin{array}{c}\mathrm{FL} \\
\text { (me) } \\
\text { or S }\end{array}$ & $\begin{array}{l}\mathrm{FL} \\
\text { (me) } \\
\text { or S }\end{array}$ & $\mathrm{P}$ & $\begin{array}{l}\mathrm{FL} \\
\text { (me) } \\
\text { or S }\end{array}$ & $\mathrm{P}$ or $\mathrm{S}$ & $\mathrm{P}$ or $\mathrm{S}$ & $\begin{array}{l}\mathrm{FL}(\mathrm{me}) \\
\text { or } \mathrm{S}\end{array}$ \\
\hline Pigment production & - & $\stackrel{+}{\mathrm{F}^{a}}$ & $\stackrel{+}{\mathrm{F} \text { and/or } \mathrm{C}}$ & $\stackrel{+}{\mathrm{F}^{b}}$ & - & $\begin{array}{c}(+) \\
\mathrm{F}\end{array}$ & $\stackrel{+}{\mathrm{F} \text { and/or } \mathrm{C}}$ & ${ }_{\mathrm{C}}^{+}$ & ${ }_{\mathrm{F}}^{+}$ & - & $\stackrel{+}{\mathrm{C}^{e}}$ & $\stackrel{+}{\mathrm{C}}$ & $\stackrel{+}{\mathrm{C}}$ & $-/(+)$ & $\stackrel{+}{\mathrm{C}}$ & $+/(+)$ & - & $\begin{array}{l}+ \\
\mathrm{F}\end{array}$ \\
\hline Gliding motility & - & + & + & - & - & - & $11^{d}$ & + & - & - & - & $\mathrm{v}$ & - & - & - & + & - & + \\
\hline Sea water requirement & - & - & $\mathrm{v}$ & - & - & - & - & + & - & - & $+^{e}$ & $\mathrm{v}$ & + & - & - & $\mathrm{v}$ & - & + \\
\hline Capnophilic metabolism & - & + & - & - & + & - & - & - & - & + & - & - & - & + & - & - & - & - \\
\hline Growth at: & & & & & & & & & & & & & & & & & & \\
\hline $25^{\circ} \mathrm{C}$ & + & ND & + & + & $(+)$ & + & $13^{d}$ & $\mathrm{v}$ & + & - & - & $\mathrm{v}$ & - & $\mathrm{v}$ & + & + & + & + \\
\hline $37^{\circ} \mathrm{C}$ & + & + & $\mathrm{v}$ & $\mathrm{v}$ & + & $+^{e}$ & - & - & + & + & - & - & - & + & - & $\mathrm{v}$ & + & + \\
\hline $42^{\circ} \mathrm{C}$ & $-^{f}$ & ND & - & $\mathrm{v}$ & - & - & - & - & - & + & - & - & - & + & - & - & + & + \\
\hline Growth on: & & & & & & & & & & & & & & & & & & \\
\hline MacConkey agar & - & - & ND & $\mathbf{v}^{g}$ & - & + & ND & - & + & - & ND & \lrcorner$^{h}$ & - & - & ND & ND & + & ND \\
\hline$\beta$-Hydroxybutyrate & - & ND & ND & $+^{i}$ & $\mathrm{ND}$ & + & ND & - & + & ND & $\mathrm{ND}$ & $-^{h}$ & - & ND & $\mathrm{ND}$ & ND & + & $\mathrm{ND}$ \\
\hline Acid production from: & & & & & & & & & & & & & & & & & & \\
\hline Glucose & - & + & $\mathrm{v}$ & $t^{j}$ & + & $t^{e}$ & $\mathrm{v}$ & + & - & $\mathrm{v}$ & + & $\mathrm{v}$ & - & + & $\mathrm{v}$ & $\mathrm{ND}$ & - & + \\
\hline Sucrose & - & $+^{k}$ & $\mathrm{v}$ & $\underline{\mathrm{v}}$ & - & - & $\mathrm{v}$ & - & - & - & $\mathrm{v}$ & $-^{h}$ & - & - & $\mathrm{v}$ & ND & - & + \\
\hline Production of: & & & & & & & & & & & & & & & & & & \\
\hline Dnase & - & $\mathrm{ND}$ & $\mathrm{v}$ & + & $\mathrm{ND}$ & + & $\mathrm{v}$ & + & + & - & ND & + & - & $\mathrm{ND}$ & + & + & - & + \\
\hline Urease & + & $\mathrm{v}$ & $\mathrm{v}$ & $\underline{\mathrm{v}}$ & - & $\mathrm{v}$ & v & - & + & + & - & $\mathrm{v}$ & - & $\mathrm{v}$ & $\mathrm{v}$ & $\mathrm{ND}$ & - & - \\
\hline Catalase & + & $\mathrm{v}$ & + & + & + & + & $+/(+)$ & + & + & - & $+/(+)$ & + & + & + & + & + & + & + \\
\hline Indole & + & - & ND & $t^{j}$ & - & + & - & - & - & - & - & $-^{h}$ & - & $\mathrm{v}$ & $\mathrm{ND}$ & ND & + & + \\
\hline$\beta$-Galactosidase & - & $\mathrm{v}$ & ND & $\mathrm{v}$ & + & - & $\mathrm{v}$ & - & - & + & $\mathrm{v}$ & - & $\mathrm{v}$ & - & + & $\mathrm{ND}$ & - & + \\
\hline Nitrate reduction & - & $\mathrm{v}$ & $\mathrm{v}$ & $\mathrm{v}$ & - & - & $\mathrm{v}$ & - & - & - & - & - & - & - & + & $\mathrm{v}$ & - & + \\
\hline Carbohydrate utilization & - & $\mathrm{v}$ & ND & + & + & $\mathrm{v}$ & $\mathrm{v}$ & + & - & + & + & + & - & + & + & ND & - & + \\
\hline
\end{tabular}


Table 2 (cont.)

\begin{tabular}{|c|c|c|c|c|c|c|c|c|c|c|c|c|c|c|c|c|c|c|}
\hline & 1 & 2 & 3 & 4 & 5 & 6 & 7 & 8 & 9 & 10 & 11 & 12 & 13 & 14 & 15 & 16 & 17 & 18 \\
\hline Degradation of: & & & & & & & & & & & & & & & & & & \\
\hline Agar & - & - & + & - & - & - & $\mathrm{v}$ & - & - & - & - & - & - & - & - & - & - & + \\
\hline Starch & - & $\mathrm{v}$ & + & $\mathrm{v}$ & $\mathrm{ND}$ & $\underline{\mathrm{v}}$ & $11^{d}$ & + & - & ND & $+/(+)$ & + & - & ND & + & $\mathrm{v}$ & - & $\mathrm{v}$ \\
\hline Aesculin & - & $\mathrm{v}$ & ND & + & + & - & $10^{a}$ & + & - & - & v & $\mathrm{v}$ & - & $\mathrm{v}$ & + & - & - & + \\
\hline Gelatin & + & $\mathrm{v}$ & $\mathrm{v}$ & + & - & + & $11^{a}$ & $\mathrm{v}$ & + & - & $\mathrm{v}$ & $\mathrm{v}$ & $\mathrm{v}$ & + & + & + & + & + \\
\hline Resistance to penicillin $\mathrm{G}$ & - & - & ND & $+^{i}$ & ND & + & $\mathrm{v}$ & ND & ND & $\mathrm{v}$ & ND & ND & ND & - & ND & $-{ }^{l}$ & - & $\mathrm{ND}$ \\
\hline $\mathrm{G}+\mathrm{C}$ content $(\mathrm{mol} \%)$ & $35-37$ & $36-44$ & $32-42$ & $33-38$ & $35-36$ & $31-33$ & $32-37$ & $36-38$ & $30-38$ & $37-39$ & $31-34$ & $32-39$ & $27-29$ & $29-37$ & $37-38$ & $30-32$ & $37-38$ & $42-43$ \\
\hline
\end{tabular}

a, Type of pigment in Capnocytophaga gingivalis. Not determined in the six other Capnocytophaga species.

b, Chryseobacterium meningosepticum strains are either not pigmented or produce a weak yellow pigment (e.g. the type strain). Members of all other Chryseobacterium species produce a bright yellow to orange pigment.

$c$, Type of pigment in Polaribacter glomeratus. Not determined in the three other Polaribacter species.

$d$, Number of species positive for this characteristic among the 14 valid Flavobacterium species. Only specified when most (i.e. 10 or more) species are positive.

$e$, Most strains are positive for this characteristic.

$f$, Most strains are negative for this characteristic.

$g$, Strain dependent for Chryseobacterium indologenes. Positive for all other Chryseobacterium species except Chryseobacterium scophthalmum and 'Chryseobacterium proteolyticum'.

h, Negative for Psychroflexus torquis (Bowman, personal communication), not determined for Psychroflexus gondwanensis.

$i$, Not determined for 'Chryseobacterium proteolyticum', positive for all other Chryseobacterium species.

j, Positive for all Chryseobacterium species, except Chryseobacterium scophthalmum.

$k$, Positive for all Capnocytophaga species, except Capnocytophaga canimorsus.

l, Negative for Tenacibaculum maritimum (Burchard, 1999). Not determined in the three other Tenacibaculum species. 
recently described genera Cellulophaga, Gelidibacter, Polaribacter, Psychroflexus, Psychroserpens, Salegentibacter and Zobellia (Gosink et al., 1998; Barbeyron et al., 2001; J. P. Bowman, personal communication; P. Nielsen, personal communication) and members of the recently described Flavobacterium species (J. P. Bowman, personal communication). This characteristic distinguishes members of the family from those of the genus Cytophaga, now restricted to cellulolytic organisms (Nakagawa \& Yamasato, 1996). It is essential (i) that members of new taxa in the family Flavobacteriaceae be tested for their ability to degrade filter paper on both a nutrient-containing agar (presence of a cellulase) and on a mineral agar (ability to use cellulose as only carbon source) (Reichenbach, 1992a) and (ii) that the cellulose derivatives that are used be specified.

\section{Minimal standards for the description of genera classified in the family Flavobacteriaceae}

The main differential characteristics for separating the genera classified in the family Flavobacteriaceae are listed in Table 2, apart from the phylogenetic data (see above) and the properties included in the description of the family. The tests used to determine these characteristics should be considered as the minimal standards for delineation of new genera. The conditions in which the tests are performed are critical for the reliability and reproducibility of the results, hence the recommended procedures described below should be followed.

Determination of pigments. Members of most genera classified in the family Flavobacteriaceae produce light to bright yellow or orange pigments though nonpigmented taxa (Bergeyella zoohelcum, Coenonia anatina, Ornithobacterium rhinotracheale and Weeksella virosa) and strains (e.g. some Chryseobacterium meningosepticum strains, including the type strain) do occur. These pigments may belong to the carotenoid or to the flexirubin types depending on the genus. However, the genus Flavobacterium includes carotenoid-producing and flexirubin-producing species, as well as species that produce both types of pigment (Reichenbach, 1989; Bernardet et al., 1996). Carotenoid pigments are usually produced by members of marine species while flexirubin pigments are more frequently associated with clinical, freshwater or soil organisms (Reichenbach, 1989). Pigments are usually non-diffusible, except the beige pigment produced by members of Riemerella species on some solid media (e.g. trypcase-soy agar) (J.-F. Bernardet, unpublished results).

Chromatography and spectrophotometry are the most accurate techniques for determining the type of pigment produced by a bacterial strain (Weeks, 1981) but, when it is not possible to use these approaches, a very simple test may be performed: colonies having a flexirubin type of pigment exhibit an immediate colour shift from yellow or orange to red, purple or brown when flooded with $20 \% \mathrm{KOH}$, and revert to their initial colour when flooded by an acidic solution once the excess of $\mathrm{KOH}$ has been removed (Reichenbach, 1989). It is strongly recommended that the test be performed on a small mass of bacterial cells collected with a loop and deposited on a glass slide placed on a white background as the colour-shift may pass unnoticed when the $\mathrm{KOH}$ solution is poured directly over a thin colony on an agar plate (J.-F. Bernardet, unpublished results). If possible, a second similar mass of bacteria should be deposited on the slide so that one of the preparations can be flooded with $\mathrm{KOH}$; the resulting colour may be then compared with the initial colour of the other mass. This colour change is not absolutely specific for the flexirubin type of pigment (Fautz \& Reichenbach, 1980), but it is still helpful when combined with the results of other tests.

Gliding motility. This type of bacterial motility is not restricted to the Cytophaga-Flavobacterium-Bacteroides phylum (Burchard, 1981; Reichenbach, 1989). However, this property is important for differentiating between genera classified in the family Flavobacteriaceae, though some precautions need to be taken as its unequivocal recognition is not always easy. Gliding motility is highly dependent on growth conditions such as the temperature (McGrath et al., 1990) and the concentration of nutrients in the growth medium; the latter should preferably be low (Reichenbach \& Dworkin, 1981). When gliding is strongly suspected but is not readily observed by microscopic examination of a drop of liquid culture with a conventionally used cover slip, it should be tested using the hanging drop technique: the cover slip on which the drop has been deposited should be turned upside down and placed on tiny stands on a glass slide; bacteria are then observed through the cover slip. Gliding must be checked on the edge of the hanging drop and at the bottom surface of the cover slip as this phenomenon is exclusively exhibited by bacteria in contact with a solid surface. The movements involved in gliding motility have been well described elsewhere (Reichenbach \& Dworkin, 1981; Reichenbach, 1989). When gliding motility is very slow and hardly noticeable, it may be detected by comparing the position of bacteria in the same area at an interval of several minutes. Gliding can usually be suspected from the more or less rhizoidal aspect of the edge of the colonies (provided the agar is not too dry) but it cannot usually be detected in bacteria collected on agar and suspended in saline. Direct microscopic examination of the edge of a young colony on an open agar plate (at the highest magnification possible without using immersion oil) may reveal either gliding itself or the slime tracks left on agar by gliding bacteria (Burchard, 1981; Reichenbach, 1992a; J.-F. Bernardet, unpublished results). Chamber culture may also be used (Reichenbach \& Dworkin, 1981). The use of phase-contrast microscopy is always preferable to visualize gliding motility, but this technique may be difficult to apply on agar plates and on hanging drops. 
Salinity requirement. The salinity requirement of members of a potentially new taxon is an important property to be investigated since several genera included in the family Flavobacteriaceae are composed of strains retrieved from sea water, ice or sediments, marine fish, beach mud, marine algae, hypersaline lakes or lakes with salinity similar to that of sea water (see Table 1) (Bowman et al., 1997, 1998; Gosink et al., 1998; Barbeyron et al., 2001). It must be clearly shown whether isolates merely tolerate sea water (e.g. members of all Chryseobacterium species are able to grow on marine agar although only members of two of them were actually isolated from marine environments; J.-F. Bernardet, unpublished results) or if they really require a high salinity. In the latter case, it is necessary to determine whether they have a requirement for artificial or natural sea water (pure or diluted) or if the mere addition of $\mathrm{NaCl}$ to standard media facilitates bacterial growth. The salinity range and the optimal salinity should be determined when $\mathrm{NaCl}$ is sufficient for growth.

Capnophilic metabolism. Members of most genera assigned to the family Flavobacteriaceae are composed of aerobic organisms. However, Capnocytophaga, Coenonia, Ornithobacterium and Riemerella strains exhibit various levels of capnophilic metabolism. Primary isolation and initial in vitro growth should be performed on blood agar plates incubated in microaerobic conditions [i.e. a $\mathrm{CO}_{2}$-enriched $(5-10 \%)$ and $\mathrm{O}_{2}$-depleted (5-10\%) atmosphere or a moisture-saturated atmosphere of $5 \% \mathrm{O}_{2}, 10 \% \mathrm{CO}_{2}$ and $85 \% \mathrm{~N}_{2}$ in a commercial gas-generation system] as these conditions provide the highest isolation rates and optimal growth (K.-H. Hinz, personal communication). After several subcultivations, some strains may be adapted to grow under aerobic conditions, although growth is always significantly better under microaerobic conditions (Segers et al., 1993a; Vandamme et al., 1994b, 1996b, 1999; Vancanneyt et al., 1999). Growth should be tested under both conditions. Growth is usually very poor or absent under strict anaerobic conditions.

Determination of fatty acid methyl esters. When the necessary equipment [i.e. gas-liquid chromatography (Vauterin et al., 1991; Suzuki et al., 1993)] and experience are available, this technique provides high quality taxonomic information, mainly at the generic and specific levels (Vandamme et al., 1996a). The predominant fatty acids found in members of the family Flavobacteriaceae are usually characteristic of genera though some fatty acid profiles help to differentiate species (Vandamme et al., 1994b, 1996b; Bernardet et al., 1996; Vancanneyt et al., 1996; Bowman et al., 1997, 1998; Gosink et al., 1998; Barbeyron et al., 2001). Comparison between fatty acid profiles yielded by different experiments is only possible when culture conditions are standardized as these conditions may markedly affect fatty acid composition (McGrath et al., 1990).

Determination of DNA base composition. Determination of the base composition of bacterial DNA is important for the description of new species since the range of $\mathrm{G}+\mathrm{C}$ content of genera classified in the family Flavobacteriaceae is relatively wide. Members of most genera can be assigned to one of three groups according to their $\mathrm{G}+\mathrm{C}$ content: very low (approx. 27-32 mol \%), intermediate (approx. 33-38 mol \%) and medium (approx. 39-44 mol\%) (see Table 2). The procedures required for determinating $\mathrm{G}+\mathrm{C}$ content have been described in detail in minimal standards recommended for other bacterial groups (Vincent LévyFrébault \& Portaels, 1992). The DNA of a reference strain, such as the type strain of Escherichia coli $(51 \mathrm{~mol} \% \mathrm{G}+\mathrm{C})$ should be included so that the $\mathrm{G}+\mathrm{C}$ content of the tested strains can be expressed relative to the reference strain (Ursing et al., 1994). Species descriptions should include information on the $G+C$ content of the proposed type strain, the range of $\mathrm{G}+\mathrm{C}$ content for all strains tested, and the procedure used to acquire these results.

\section{Minimal standards for the description of species classified in the family Flavobacteriaceae}

Phenotypic characteristics. The description of a new species within the different genera classified in the family Flavobacteriaceae should be based on characteristics necessary for assigning the new taxon to the corresponding genus and on characteristics that serve to differentiate the new taxon from existing taxa of the genus. The main phenotypic properties used for differentiating between species are listed below. The recommended tests used to acquire these data form the minimal standards for descriptions of new species within the different genera and taxa. However, when different methods are available to test phenotypic characteristics, they have only rarely been compared on a given species and usually not on all members of a genus. For instance, it has been demonstrated that the presence of cytochrome oxidase in some Flavobacterium species was more readily evidenced using discs impregnated with dimethyl- $p$-phenylenediamine oxalate than using liquid tetramethyl- $p$-phenylenediamine dihydrochloride reagents (Koski et al., 1993; J.-F. Bernardet, unpublished results). However, this comparison has not been performed on all Flavobacterium species nor in other genera; consequently, the recommendation of the disc method cannot be extended to the whole genus, even less to other genera. A similar situation occurred when the production of $\beta$-galactosidase was tested in Chryseobacterium (Holmes et al., 1984b; Bruun \& Ursing, 1987; J.-F. Bernardet, unpublished results) and Coenonia (Vandamme et al., 1999) species using different substrates (i.e. o-nitrophenyl- $\beta$-D-galactopyranoside on filter paper discs and in API $20 \mathrm{E}$ galleries, $p$-nitrophenyl- $\beta$-D-galactopyranoside in API 20NE and API ID 32E galleries, or 2-naphthyl- $\beta$-D-galactopyranoside in API ZYM galleries). Moreover, the members of the different genera have very different growth requirements (i.e. ionic content, temperature, composition of the media and atmosphere). For these reasons, the tests recom- 
mended below for the different genera are mostly those successfully used by authors who have studied them extensively; the corresponding references are given in parentheses after the name of each taxon. When the only publication available is the original description of the genus, the methods used to determine its characteristics should preferably be followed to describe new taxa in this genus. When no particular method was specified, standardized, well-described tests and methods (e.g. West \& Colwell, 1984; Barrow \& Feltham, 1993; Gerhardt et al., 1994; Smibert \& Krieg, 1994; Richard \& Kiredjian, 1995) should preferably be followed. When $\mathrm{G}+\mathrm{C}$ determinations clearly help to differentiate between species, this property should be added to the list of phenotypic characteristics.

Bergeyella zoohelcum (Holmes et al., 1986a, 1986b; Holmes, 1992). Members of this species were originally classified in the genus Weeksella, hence its differentiation from $W$. virosa relied on its inability to grow at $42{ }^{\circ} \mathrm{C}$, on MacConkey agar, and on $\beta$-hydroxybutyrate, as well as on its urease activity on Christensen's medium (Christensen, 1946). These characteristics now differentiate the genera Bergeyella and Weeksella (see Table 2).

Capnocytophaga species (Socransky et al., 1979; Brenner et al., 1989; Holt \& Kinder, 1989; Yamamoto et al., 1994). Hydrolysis of aesculin (e.g. Holdeman et al., 1977), dextran and gelatin; hydrolysis of starch (for example using the method of Barrow \& Feltham, 1993) and urea (preferably on Christensen's medium; Christensen, 1946); $\beta$-galactosidase activity; acid production from lactose, melibiose and raffinose (e.g. Holdeman et al., 1977); production of catalase (with percentage of $\mathrm{H}_{2} \mathrm{O}_{2}$ solution and time of observation given) and cytochrome oxidase (e.g. Barrow \& Feltham, 1993); $\beta$-haemolysis; ability to grow aerobically; presence of granular inclusions; nitrate reduction (e.g. Holdeman et al., 1977); and $\mathrm{G}+\mathrm{C}$ content of DNA.

Cellulophaga species (Johansen et al., 1999; Bowman, 2000). Type of pigment and sea water requirement (see above); production of cytochrome oxidase; acid production from glucose and sucrose; DNase and urease activities; nitrate reduction; utilization of carbohydrates (for example using the Biolog GN MicroPlate method); degradation of alginic acid $(2 \%, w / v$, in a mineral medium; e.g. van der Meulen et al., 1974) and autoclaved yeast cells (tested on VY/2 substrate containing $20 \%$ sea salts, according to Reichenbach, 1989); degradation of casein, elastin, fibrinogen and gelatin $(0 \cdot 5,0 \cdot 1,0 \cdot 1$ and $0 \cdot 6 \%, \mathrm{w} / \mathrm{v}$, respectively, added to Difco marine agar 2216 or to trypticase-soy agar containing $20 \%$ sea salts); and G + C content of DNA.

Chryseobacterium species (Yabuuchi et al., 1983, 1990; Holmes, 1992; Mudarris et al., 1994; Hugo, 1997; Yamaguchi \& Yokoe, 2000). Growth on cetrimide and MacConkey agars and at 5, 37 and $42{ }^{\circ} \mathrm{C}$; acid production from different sugars (preferably tested in ammonium salt medium; Barrow \& Feltham, 1993); nitrate and nitrite reduction (for example using the method described by West \& Colwell, 1984); production of L-phenylalanine deaminase (preferably by the technique of Richard \& Kiredjian, 1995), urease and indole (preferably using a very dense suspension of bacteria in a urea-indole medium and Kovács' reagent; Richard \& Kiredjian, 1995; Hugo, 1997), and $\mathrm{H}_{2} \mathrm{~S}$ (on commercial Kliger iron agar, according to Smibert \& Krieg, 1984); formation of a precipitate on $10 \%$ egg yolk nutrient (Barrow \& Feltham, 1993) or trypcase-soy agar; hydrolysis of starch and Tween 80 (for example using the methods of West \& Colwell, 1984); hydrolysis of L-tyrosine on $0.5 \%$ L-tyrosine nutrient (Barrow \& Feltham, 1993) or trypcase-soy agar; and $\beta$-galactosidase activity (preferably using commercial ONPG discs or API 20NE galleries). Chryseobacterium indologenes and Chryseobacterium gleum differ in their ability to degrade aesculin after $4 \mathrm{~h}$ (Yabuuchi et al., 1990).

Coenonia anatina. The properties considered characteristic of this taxon and the recommended tests used to acquire them are listed in the species description (Vandamme et al., 1999).

Empedobacter brevis. An extensive list of the characteristics of this taxon and of the recommended tests used to acquire them were given by Holmes et al. (1978).

Flavobacterium species (Holmes et al., 1984a; Reichenbach, 1989, 1992a; Bernardet \& Grimont, 1989; Bernardet et al., 1996 and references therein; McCammon et al., 1998; McCammon \& Bowman, 2000). Morphology of colonies on Anacker and Ordal's agar (Anacker \& Ordal, 1955); adherence of colonies to the agar and Congo red adsorption (see below); growth on marine, nutrient and trypcase-soy agars and at $25^{\circ} \mathrm{C}$; presence of gliding motility and production of flexirubin type of pigments (see above); utilization of glucose as a sole carbon and energy source (for example using API 20NE galleries; McCammon et al., 1998); production of acid from carbohydrates aerobically, preferably tested in ammonium salt medium (e.g. Barrow \& Feltham, 1993); degradation of aesculin (using a commercial aesculin agar), agar, alginate (e.g. West \& Colwell, 1984), carboxymethylcellulose (for example using a $0.5 \%$ CMC overlay agar; $\mathrm{McCa}-$ mmon et al., 1998), casein, chitin (for example using a $20 \%$ chitin overlay agar; Reichenbach \& Dworkin, 1981), DNA (on any commercial DNA agar; Bernardet \& Kerouault, 1989), gelatin, pectin (preferablyaccordingtoHildebrand, 1971), starch, L-tyrosine and urea; production of a brown diffusible pigment on L-tyrosine agar; formation of a precipitate on egg yolk agar (e.g. Barrow \& Feltham, 1993); $\beta$-galactosidase activity (preferably using commercial ONPG filter paper discs); susceptibility to vibriostatic compound $\mathrm{O} / 129$; production of $\mathrm{H}_{2} \mathrm{~S}$ and cytochrome oxidase; and reduction of nitrate. 
Gelidibacter algens. The properties considered characteristic of this taxon and the recommended tests used to acquire them were given in the species description (Bowman et al., 1997).

Myroides species (Vancanneyt et al., 1996). The two Myroides species are mostly differentiated by their profiles in Biotype 100 galleries and Biolog GN MicroPlate assays, and by the slightly different $\mathrm{G}+\mathrm{C}$ content of their DNAs.

Ornithobacterium rhinotracheale. The properties considered characteristic of this taxon and the recommended tests used to acquire them were listed in the species description (Vandamme et al., 1994b).

Polaribacter species (Gosink et al., 1998). Cell morphology, coil formation and presence of gas vesicles; growth at $21{ }^{\circ} \mathrm{C}$; hydrolysis of aesculin and gelatin (e.g. Smibert \& Krieg, 1994); sea water requirement; utilization of DL-malate, L-glutamate, glycerol and $\mathrm{N}$ acetyl- $\beta$-glucosamine as carbon sources; oxidation/ fermentation of a variety of sugars; $\beta$-galactosidase activity; and absorbance wavelength of ethanolic extracts.

Psychroflexus species (Bowman et al., 1998). Production of filamentous cells longer than $100 \mu \mathrm{m}$; presence of gliding motility; optimal growth temperature and temperature range; optimal salinity and salinity range; yeast extract requirement; hydrolysis of aesculin, gelatin and urea; production of acid from various sugars and from glycerol; and $\mathrm{G}+\mathrm{C}$ content of DNA.

Psychroserpens burtonensis. The properties considered characteristic of this taxon and the recommended tests used to acquire them were given in the species description (Bowman et al., 1997).

Riemerella species (Vancanneyt et al., 1999). The only phenotypic characteristics that clearly differentiate the two Riemerella species are pigment production on Columbia blood agar and aesculin hydrolysis.

Salegentibacter salegens. The properties considered characteristic of this taxon and the recommended tests used to acquire them were given in the original description of the species (Dobson et al., 1993) and by McCammon \& Bowman (2000).

Tenacibaculum species (Wakabayashi et al., 1986; Hansen et al., 1992; Suzuki et al., 2001). Pigmentation of colonies and sea water requirement (see above and Suzuki et al., 2001); growth at 4, 30 and $37^{\circ} \mathrm{C}$; Congo red adsorption, adherence of colonies to the agar and production of high-viscosity extracellular polysaccharide in liquid culture (see below); growth in pellicle in liquid culture and utilization of sodium glutamate as a nitrogen source (Hansen et al., 1992); nitrate reduction and degradation of starch (preferably according to the methods of Smibert \& Krieg, 1994); and production of ammonia (according to Lewin \& Lounsbery, 1969).
Weeksella virosa, see Bergeyella zoohelcum.

Zobellia species (Barbeyron et al., 2001). Morphology and colour of colonies; degradation of starch; intensity of the degradation of carrageenans; and assimilation of various sugars in commercial galleries.

Experience is needed to successfully carry out some of the above-mentioned phenotypic tests. Provided identical growth conditions are used, colony morphology may be used to differentiate some species, for instance, in the genus Flavobacterium (Reichenbach, 1989; J.-F. Bernardet, unpublished results). Characteristics such as iridescent waves and rhizoid edges are best revealed under stereomicroscopic examination $(\times 20)$ through oblique transmitted light (Bernardet, 1989b; Bernardet \& Kerouault, 1989). However, some strains may exhibit different colony types on the same agar plate (e.g. Flavobacterium columnare, Flavobacterium psychrophilum and Tenacibaculum maritimum strains) (Bernardet, 1989a, 1989b; Bernardet \& Kerouault, 1989; J.-F. Bernardet, unpublished results). Strains should preferably be grown on relatively poor media, such as Anacker and Ordal's (Anacker \& Ordal, 1955) to observe the typical swarming colonies exhibited by most gliding bacteria. Adherence of colonies to the agar is also a useful feature; it can be determined by trying to collect colonies on agar plates with a loop. Separating colonies from agar can be nearly impossible in some Flavobacterium columnare and Cellulophaga/Zobellia uliginosa strains, but adherence may be lost after several subcultures (J.-F. Bernardet, unpublished results). Colonies of members of some other species may exhibit a sticky or mucoid consistency; in such cases, the viscosity of liquid cultures is usually increased due to the production of slime (e.g. Tenacibaculum maritimum) (J.-F. Bernardet, unpublished results). Congo red adsorption is tested by directly flooding some colonies on the agar with a few drops of a $0.01 \%$ aqueous solution of the dye; after about $2 \mathrm{~min}$, the dye is gently rinsed with water and the colour of these colonies compared to that of colonies which have not been flooded. In the case of Flavobacterium columnare, the Congo red-staining material has been shown to be an extracellular galactosamine glycan in the slime (Johnson \& Chilton, 1966).

Genomic analyses. Relationships to neighbouring species should be determined by quantitative DNADNA hybridization (Owen \& Pitcher, 1985). According to Wayne et al. (1987), 'The phylogenetic definition of a species generally would include strains with approximately $70 \%$ or greater DNA relatedness and with $5^{\circ} \mathrm{C}$ or less $\Delta T_{\mathrm{m}}$. Both values must be considered'. With regard to the correlation with phenotypic properties, the authors insisted that they "should agree with this definition and would be allowed to override the phylogenetic concept of species only in a few exceptional cases' and that 'a distinct genospecies that cannot be differentiated from another genospecies on the basis of any known phenotypic property not be named until they can be 
differentiated by some phenotypic property' (Wayne et al., 1987). This is important since DNA homology studies cannot be performed in all laboratories; it is thus necessary that the identification of new species be readily possible from a few phenotypic characteristics that can be tested outside specialized laboratories. Most DNA-DNA hybridization experiments performed on members of the species classified in the family Flavobacteriaceae have revealed that the $70 \%$ cut-off value proposed by Wayne et al. (1987) does make sense with respect to these taxa: strains belonging to the same species (according to phenotypic and chemotaxonomic features) share DNA relatedness well above $70 \%$ whereas DNA relatedness is distinctly below this value when strains belonging to different species (even within the same genus) are hybridized (Holmes et al., 1986a; Bernardet \& Grimont, 1989; Vandamme et al., 1994b; Bowman et al., 1997, 1998; McCammon et al., 1998; Goris et al., 1998; Vancanneyt et al., 1999; McCammon \& Bowman, 2000; Yamaguchi \& Yokoe, 2000). The range of DNA relatedness between different strains of the same species may be rather wide, from approximately $70 \%$ to close to $100 \%$ (Holmes et al., 1986b; Bernardet \& Grimont, 1989; Wakabayashi et al., 1989; Bernardet et al., 1994; Vancanneyt et al., 1996; Johanssen et al., 1999). Some strains may even exhibit a DNA relatedness value lower than $70 \%$ with most other strains of the same species (Holmes et al., 1986b; Wakabayashi et al., 1989; Goris et al., 1998; Vancanneyt et al., 1996, 1999); in some of these cases, reciprocal hybridization experiments (Yamamoto et al., 1994) or $\Delta T_{\mathrm{m}}$ values well below $5^{\circ} \mathrm{C}$ (Bernardet et al., 1996) have shown that such strains nevertheless belong to the same species. Distinct hybridization groups have been delineated within some Chryseobacterium species and Empedobacter brevis (Ursing \& Bruun, 1987, 1991) and within Flavobacterium columnare; in the latter case, these groups have been confirmed by $16 \mathrm{~S}$ rDNA restriction patterns and sequence analysis (Triyanto \& Wakabayashi, 1999). However, according to the second principle by Wayne et al. (1987) quoted above, these groups could only be considered genomic species or genomovars as no phenotypic characteristics were available to differentiate them.

The different quantitative techniques used to determine DNA relatedness are reliable (provided reciprocal values and relevant controls are included) but they yield different relative binding ratios; conversely, $\Delta T_{\mathrm{m}}$ (i.e. the percentage divergence, which measures the thermal stability of DNA hybrids) is not influenced by the method used but it cannot be determined by using the spectrophotometric method (Grimont et al., 1980). Microplate techniques are also available for DNADNA hybridization experiments (Ezaki et al., 1989), but at best they are semiquantitative and may thus not be able to resolve close genomic relationships. Although several hybridization procedures have been applied specifically to members of the family Flavobacteriaceae, a comparison of the results yielded by different methods on the same group of strains is only possible in very few cases. DNA relatedness among strains belonging to several Chryseobacterium species has been determined spectrophotometrically by the initial renaturation rate method (De Ley et al., 1970) by Mudarris et al. (1994) and Hugo et al. (1999); similar DNA relatedness values have been obtained by Bernardet (unpublished results) using the S1-nuclease method with adsorption of S1-resistant DNA onto diethylaminoethyl-cellulose filters (Popoff \& Coynault, 1980). The DNA of strains belonging to several Tenacibaculum species has been hybridized using three different techniques: the initial renaturation method (Hansen et al., 1992), an S1-nuclease method (Bernardet et al., 1994; J.-F. Bernardet, unpublished results) and a microplate method (Suzuki et al., 2001). All three techniques resulted in intraspecific DNA relatedness values higher than $85 \%$. However, there were considerable discrepancies when the DNA of the type strains of Tenacibaculum maritimum and Tenacibaculum ovolyticum were hybridized: their DNA relatedness was below $6 \%$ by the S1-nuclease method, approximately $12-35 \%$ by the microplate method, and $43 \%$ by the initial renaturation method. The DNA relatedness between several members of the two Myroides species has been determined using a microplate hybridization method and the initial renaturation method; a good correlation between the two methods was found for both intraspecific and interspecific hybridization experiments, although DNA relatedness values from the microplate method were slightly higher than those from the initial renaturation method (Goris et al., 1998). It is strongly recommended that the integrity of bacterial DNAs used in genomic studies be previously checked on an agarose gel as fragmented DNAs may yield aberrant $\mathrm{G}+\mathrm{C}$ content and DNA relatedness values (Goris et al., 1998).

Hybridization studies should include several strains of the newly proposed species, including the proposed type strain, as well as the type strains of all related species. It has been suggested that DNA homology studies also include 'those organisms not currently assigned specific status' (Graham et al., 1991), because such studies could result in their assignation to a new species. DNA-DNA hybridization experiments are laborious, hence a preliminary polyphasic study (e.g. including $16 \mathrm{~S}$ rRNA sequencing, classical phenotypic tests, protein and fatty acid profiles ... ) will help to select the test strains. However, with the exception of non-cultivable organisms (see above), 16S rRNA analysis should not be the only genomic method used for delineating new species. Although organisms that share less than $97 \% 16 \mathrm{~S}$ rRNA sequence homology rarely display more than $60 \%$ DNA homology (Stackebrandt \& Goebel, 1994, and references therein), exceptions exist (Harrington \& On, 1999; Suzuki et al., 2001). It is also well known that sequence homology values higher than $97 \%$ do not guarantee conspecificity, as shown in Capnocytophaga (Vandamme et al., 1996b) and Cellulophaga (Bowman, 2000) strains. 
Similar precautions should be taken when interpreting gyr $B$ sequences, although the DNA relatedness values between Tenacibaculum species have been shown to be more distinctly correlated to the sequence similarity of gyrB than to that of $16 \mathrm{~S}$ rRNA (Suzuki et al., 2001).

Whole-cell protein analysis. Several studies have revealed a correlation between high DNA homology and high similarity in whole-cell protein patterns obtained by SDS-PAGE (Vauterin et al., 1993; Vandamme et al., 1996a). Within the family Flavobacteriaceae, species of the genera Capnocytophaga (Vandamme et al., 1996b), Myroides (Vancanneyt et al., 1996) and Riemerella (Vancanneyt et al., 1999) can be readily differentiated by their protein profiles. This is particularly important for the genera Myroides and Riemerella, for which few characteristics are available for the differentiation of these taxa. However, for some other genera some species can be identified by their very typical protein profiles whereas some others exhibit intraspecific heterogeneity; this is, for instance, the case in the genus Flavobacterium (Bernardet et al., 1996). Consequently, whole-cell protein analysis cannot replace DNA homology in the definition of bacterial species. Moreover, in order to compare protein profiles accurately, highly standardized SDS-PAGE electrophoregrams must be scanned and numerically analysed by computer and compared to large databases.

As already mentioned above, the presence or amount of some fatty acids may also be of value for differentiating the species.

Relationship to the host. Some members of the family Flavobacteriaceae are commensal organisms or true or opportunistic pathogens. Members of certain species are aetiologic agents of diseases of humans, birds or fishes. When members of a new species are recovered from clinical or veterinary samples, data concerning their pathogenicity for the host should be provided, if available. In the case of possible animal pathogens, the disease should preferably be experimentally reproduced in order to demonstrate pathogenicity.

\section{Recognition of subspecies}

When a group of strains exhibits consistent phenotypic discrepancies with most other strains in the species but still shares a high DNA homology with them, it could be warranted subspecies rank. In order to avoid congesting bacterial nomenclature with unnecessary subspecies names, epithets such as biovar, pathovar or serovar should preferably be used when only limited information is available and pending further data.

\section{ACKNOWLEDGEMENTS}

B.H., J.F.B. and Y.N. (Chairman, Secretary and member, respectively, of the International Committee on Systematics of Prokaryotes Subcommittee on the taxonomy of Flavobacterium and Cytophaga-like bacteria) are very grateful to all other (past and present) members of the subcommittee for their careful reading of the manuscript and their helpful comments: J. P. Bowman (University of Tasmania, Department of Agricultural Science, Hobart, Tasmania, Australia), B. Bruun (Statens Seruminstitut, Department of Clinical Microbiology, København, Denmark), R. P. Burchard (University of Maryland, Baltimore County, Department of Biological Sciences, Baltimore, MD, USA), C. J. Hugo (University of the Orange Free State, Department of Food Science, Bloemfontein, South Africa), P. J. Jooste (Animal Nutrition and Animal Products Institute, Irene, South Africa), K. A. Malik (Deutsche Sammlung von Mikroorganismen und Zellkulturen, Braunschweig, Germany), T. A. McMeekin (University of Tasmania, Department of Agricultural Science, Hobart, Tasmania, Australia), W. Reichardt (International Rice Research Institute, Manila, Philippines), H. Reichenbach (Gesellschaft für Biotechnologische Forschung, Department of Natural Product Biology, Braunschweig, Germany), P. Segers (Faculteit Wetenschappen, Laboratory of Microbiology, Gent, Belgium), H. Wakabayashi (Graduate School of Agricultural and Life Sciences, Department of Aquatic Bioscience, University of Tokyo, Japan), E. Yabuuchi (Osaka City University Medical School, Department of Bacteriology, Osaka, Japan), and the late J. Ursing (Malmø University Hospital, Department of Medical Microbiology, Malmø, Sweden). The authors are also indebted to P. Segers and to M. Suzuki (Kyowa Hakko Kogyo Co., Ltd, Tokyo Research Laboratories, Tokyo, Japan) who kindly provided some $16 \mathrm{~S}$ rRNA sequences before they were deposited in databases, and to K.-H. Hinz (Klinik für Geflügel der Tierärztliche Hochschule Hannover, Germany) for helpful comments about capnophilic metabolism. In order to improve this manuscript, J. Bowman and P. Nielsen (Enzyme Research, Novo Nordisk A/S, Bagsvaerd, Denmark) kindly performed some additional phenotypic tests; the authors wish to express their sincerest thanks and appreciation for the important data they provided.

\section{NOTE ADDED IN PROOF}

After this manuscript was completed, the following taxa were added to the family Flavobacteriaceae: Flavobacterium frigidarium sp. nov. (Humphry et al., 2001), Arenibacter gen. nov., sp. nov. (Ivanova et al., 2001), Muricauda ruestringensis gen. nov., sp. nov. (Bruns et al., 2001), Aequorivita gen. nov. (including Aequorivita antarctica sp. nov., Aequorivita lipolytica sp. nov., Aequorivita crocea sp. nov. and Aequorivita sublithincola sp. nov.) (Bowman \& Nichols, 2002) and Gelidibacter mesophilus sp. nov. (Macián et al., 2002).

\section{REFERENCES}

Agbo, J. A. C. \& Moss, M. O. (1979). The isolation and characterization of agarolytic bacteria from a lowland river. J Gen Microbiol 115, 355-368.

Anacker, R. L. \& Ordal, E. J. (1955). Study of a bacteriophage infecting the myxobacterium Chondrococcus columnaris. J Bacteriol 70, 738-741.

Anderson, R. L. \& Ordal, E. J. (1961). Cytophaga succinicans sp. n., a facultatively anaerobic, aquatic myxobacterium. $J$ Bacteriol 81, 130-138.

Bandi, C., Damiani, G., Magrassi, L., Grigolo, A., Fani, R. \& Sacchi, L. (1994). Flavobacteria as intracellular symbionts in cockroaches. Proc R Soc Lond B 257, 43-48.

Barbeyron, T., L'Haridon, S., Corre, E., Kloareg, B. \& Potin, P. (2001). Zobellia galactanovorans gen. nov., sp. nov., a marine species of Flavobacteriaceae isolated from a red alga, and reclassification of 
[Cytophaga] uliginosa (ZoBell and Upham 1944) Reichenbach 1989 as Zobellia uliginosa gen. nov., comb. nov. Int J Syst Evol Microbiol 51, 985-997.

Barrow, G. I. \& Feltham, R. K. A. (1993). Cowan and Steel's Manual for the Identification of Medical Bacteria, 3rd edn. Cambridge: Cambridge University Press.

Bergey, D. H., Harrison, F. C., Breed, R. S., Hammer, B. W. \& Huntoon, F. M. (1923). Bergey's Manual of Determinative Bacteriology, 1st edn. Baltimore, MD: Williams \& Wilkins.

Bernardet, J.-F. (1989a). Etude phénotypique et génomique des bactéries appartenant aux genres Cytophaga et Flexibacter (ordre des Cytophagales) et comparaison avec le genre Flavobacterium; application à l'identification et à la taxonomie des espèces ichtyopathogènes. $\mathrm{PhD}$ thesis, Université Paris 7.

Bernardet, J.-F. (1989b). "Flexibacter columnaris": first description in France and comparison with bacterial strains from other origins. Dis Aquat $\operatorname{Org}$ 6, 37-44.

Bernardet, J.-F. \& Grimont, P. A. D. (1989). Deoxyribonucleic acid relatedness and phenotypic characterization of Flexibacter columnaris sp. nov., nom. rev., Flexibacter psychrophilus sp. nov., nom. rev., and Flexibacter maritimus Wakabayashi, Hikida, and Masumura 1986. Int J Syst Bacteriol 39, 346-354.

Bernardet, J.-F. \& Kerouault, B. (1989). Phenotypic and genomic studies of "Cytophaga psychrophila" isolated from diseased rainbow trout (Oncorhynchus mykiss) in France. Appl Environ Microbiol 55, 1796-1800.

Bernardet, J.-F., Kerouault, B. \& Michel, C. (1994). Comparative study on Flexibacter maritimus strains isolated from farmed sea bass (Dicentrarchus labrax) in France. Fish Pathol 29, 105-111.

Bernardet, J.-F., Segers, P., Vancanneyt, M., Berthe, F., Kersters, K. \& Vandamme, P. (1996). Cutting a Gordian knot: emended classification and description of the genus Flavobacterium, emended description of the family Flavobacteriaceae, and proposal of Flavobacterium hydatis nom. nov. (basonym, Cytophaga aquatilis Strohl and Tait 1978). Int J Syst Bacteriol 46, 128-148.

Borg, A. F. (1960). Studies on myxobacteria associated with diseases in salmonid fishes (Wildlife Disease, no. 8). Washington, DC: American Association for the Advancement of Science.

Bousfield, I. J. (1993). Bacterial nomenclature and its role in systematics. In Handbook of New Bacterial Systematics, pp. 318-338. Edited by M. Goodfellow \& A. G. O'Donnell. New York: Academic Press.

Bowman, J. P. (2000). Description of Cellulophaga algicola sp. nov., isolated from the surfaces of Antarctic algae, and reclassification of Cytophaga uliginosa (ZoBell and Upham 1944) Reichenbach 1989 as Cellulophaga uliginosa comb. nov. Int J Syst Evol Microbiol 50, 1861-1868.

Bowman, J. \& Nichols, D. S. (2002). Aequorivita gen. nov., a member of the family Flavobacteriaceae isolated from terrestrial and marine Antarctic habitats. Int J Syst Evol Microbiol 52 (in press).

Bowman, J. P., McCammon, S. A., Brown, J. L., Nichols, P. D. \& McMeekin, T. A. (1997). Psychroserpens burtonensis gen. nov., sp. nov., and Gelidibacter algens gen. nov., sp. nov., psychrophilic bacteria isolated from Antarctic lacustrine and sea ice habitats. Int J Syst Bacteriol 47, 670-677.

Bowman, J. P., McCammon, S. A., Lewis, T., Skerratt, J. H., Brown, J. L., Nichols, D. S. \& McMeekin, T. A. (1998). Psychroflexus torquis gen. nov., sp. nov., a psychrophilic species from Antarctic sea ice, and reclassification of Flavobacterium gondwanense (Dobson et al. 1993) as Psychroflexus gondwanense gen. nov., comb. nov. Microbiology 144, 1601-1609.

Bowman, J. P., McCammon, S. A., Lewis, T., Skerratt, J. H., Brown, J. L., Nichols, D. S. \& McMeekin, T. A. (1999). Psychroflexus gen. nov., Psychroflexus gondwanensis corrig., comb. nov. and Psychroflexus torquis sp. nov. In Validation of the Publication of New Names and New Combinations Previously Effectively Published Outside the IJSB, List no. 68. Int J Syst Bacteriol 49, 1-3.

Breed, R. S. (1957a). The genus Agarbacterium. In Bergey's Manual of Determinative Bacteriology, 7th edn, pp. 322-328. Edited by R. S. Breed, E. G. D. Murray \& N. R Smith. Baltimore: Williams \& Wilkins.
Breed, R. S. (1957b). The genus Pasteurella. In Bergey's Manual of Determinative Bacteriology, 7th edn, pp. 395-402. Edited by R. S. Breed, E. G. D. Murray \& N. R. Smith. Baltimore: Williams \& Wilkins. Brenner, D. J., Hollis, D. G., Fanning, G. R. \& Weaver, R. E. (1989). Capnocytophaga canimorsus sp. nov. (formerly CDC group DF-2), a cause of septicemia following dog bite, and C. cynodegmi sp. nov., a cause of localized wound infection following dog bite. J Clin Microbiol 27, 231-235.

Brisou, J., Tysset, C., Jacob, A. \& Valette, L. (1960). Contribution à l'étude de deux germes du genre Flavobacterium saprophytes d'anguille d'eau douce (Anguilla vulgaris Turton). Arch Inst Pasteur Algérie 38, 500-509.

Brosius, J., Palmer, M. L., Kennedy, P. J. \& Noller, H. F. (1978). Complete nucleotide sequence of a $16 \mathrm{~S}$ ribosomal RNA gene from Escherichia coli. Proc Natl Acad Sci U S A 75, 4801-4805.

Bruner, D. W. \& Fabricant, J. (1954). A strain of Moraxella anatipestifer (Pfeifferella anatipestifer) isolated from ducks. Cornell Vet $\mathbf{4 4}$, 461-464.

Bruns, A., Rohde, M. \& Berthe-Corti, L. (2001). Muricauda ruestringensis gen. nov., sp. nov., a facultatively anaerobic, appendaged bacterium from German North sea intertidal sediment. Int J Syst Evol Microbiol 51, 1997-2006.

Bruun, B. \& Ursing, J. (1987). Phenotypic characterization of Flavobacterium meningosepticum strains identified by DNA-DNA hybridization. Acta Pathol Microbiol Immunol Scand Sect B 95, 41-47.

Buchanan, R. E. (1994). Chemical terminology and microbiological nomenclature. Int J Syst Bacteriol 44, 588-590.

Burchard, R. P. (1981). Gliding motility of prokaryotes: ultrastructure, physiology, and genetics. Annu Rev Microbiol 35, 497-529.

Burchard, R. P. (1999). Beta-lactam antibiotic selection of nonswarming mutants of Flexibacter maritimus. Can J Microbiol 45, 786-790.

Campbell, L. L. (1957). Genus Beneckea Campbell. In Bergey's Manual of Determinative Bacteriology, 7th edn, pp. 328-332. Edited by R. S. Breed, E. G. D. Murray \& N. R. Smith. Baltimore: Williams \& Wilkins.

Campbell, L. L. \& Williams, O. B. (1951). A study of chitin-decomposing micro-organisms of marine origin. J Gen Microbiol 5, 894-905. Chester, F. D. (1897). Report of the mycologist: bacteriological work. Del Agr Exp Sta Bull 9, 38-145.

Chester, F. D. (1901). A Manual of Determinative Bacteriology. New York: Macmillan.

Christensen, W. B. (1946). Urea decomposition as a mean of differentiating Proteus and paracolon cultures from each other and from Salmonella and Shigella. J Bacteriol 52, 461-465.

Clayton, R. A., Sutton, G., Hinkle, P. S., Jr, Bult, C. \& Fields, C. (1995). Intraspecific variation in small-subunit rRNA sequences in GenBank: why single sequences may not adequately represent prokaryotic taxa. Int J Syst Bacteriol 45, 595-599.

Colwell, R. R., Citarella, R. V. \& Chen, P. K. (1966). DNA base composition of Cytophaga marinoflava $\mathrm{n}$. sp. determined by buoyant density measurements in cesium chloride. Can J Microbiol 12, 10991103.

Dasch, G. A., Weiss, E. \& Chang, K.-P. (1984). Genus Blattabacterium Hollande and Favre 1931. In Bergey's Manual of Systematic Bacteriology, vol. 1, pp. 830-831. Edited by N. R. Krieg \& J. G. Holt. Baltimore: Williams \& Wilkins.

Davis, H. S. (1922). A new bacterial disease of fresh-water fishes. Bull US Bur Fish 38, 261-280.

Dees, S. B., Moss, C. W., Hollis, D. G. \& Weaver, R. E. (1986). Chemical characterization of Flavobacterium odoratum, Flavobacterium breve, and Flavobacterium-like groups IIe, IIh, and IIf. J Clin Microbiol 23, 267-273.

De Ley, J., Cattoir, H. \& Reynaerts, A. (1970). The quantitative measurement of DNA hybridization from renaturation rates. Eur $J$ Biochem 12, 133-142.

Desolme, B. \& Bernardet, J.-F. (1996). Freeze-drying of Flavobac- 
terium columnare, Flavobacterium psychrophilum and Flexibacter maritimus. Dis Aquat Org 27, 77-80.

Dewhirst, F. E., Fox, J. G. \& On, S. L. W. (2000). Recommended minimal standards for describing new species of the genus Helicobacter. Int J Syst Evol Microbiol 50, 2231-2237.

Dobson, S. J., Colwell, R. R., McMeekin, T. A. \& Franzmann, P. D. (1993). Direct sequencing of the polymerase chain reaction-amplified $16 \mathrm{~S}$ rRNA gene of Flavobacterium gondwanense sp. nov. and Flavobacterium salegens sp. nov., two new species from a hypersaline Antarctic lake. Int J Syst Bacteriol 43, 77-83.

Dorey, M. J. (1959). Some properties of a pectinolytic soil flavobacterium. J Gen Microbiol 20, 91-104.

Euzéby, J.P. (1997). List of bacterial names with standing in nomenclature: a folder available on the Internet (URL http://www. bacterio. cict. fr/). Int J Syst Bacteriol 47, 590-592.

Ezaki, T., Hashimoto, Y. \& Yabuuchi, E. (1989). Fluorometric deoxyribonucleic acid-deoxyribonucleic acid hybridization in microdilution wells as an alternative to membrane filter hybridization in which radioisotopes are used to determine genetic relatedness among bacterial strains. Int J Syst Bacteriol 39, 224-229.

Fautz, E. \& Reichenbach, H. (1980). A simple test for flexirubin-type pigments. FEMS Microbiol Lett 8, 87-91.

Felsenstein, J. (1985). Confidence limits of phylogenies: an approach using the bootstrap. Evolution 39, 783-791.

Frankland, G. C. \& Frankland, P. F. (1889). Ueber einige typische Mikroorganismen im Wasser und im Boden. Z Hyg 6, 373-400.

Freney, J., Kloos, W. E., Hajek, V., Webster, J. A., Bes, M., Brun, Y. \& Vernozy-Rozand, C. (1999). Recommended minimal standards for description of new staphylococcal species. Int J Syst Bacteriol 49, 489-502.

Garnjobst, L. (1945). Cytophaga columnaris (Davis) in pure culture: a myxobacterium pathogenic to fish. J Bacteriol 49, 113-128.

Gerhardt, P., Murray, R. G. E., Wood, W. A. \& Krieg, N. R. (1994). Methods for General and Molecular Bacteriology. Washington, DC: American Society for Microbiology.

Gherna, R. \& Woese, C. R. (1992). A partial phylogenetic analysis of the "Flavobacter-Bacteroides" phylum: basis for taxonomic restructuring. Syst Appl Microbiol 15, 513-521.

Goris, J., Suzuki, K., De Vos, P., Nakase, T. \& Kersters, K. (1998). Evaluation of a microplate DNA-DNA hybridization method compared with the initial renaturation method. Can J Microbiol 44, 1148-1153.

Gosink, J. J., Woese, C. R. \& Staley, J. T. (1998). Polaribacter gen. nov., with three new species, $P$. irgensii sp. nov., $P$. franzmannii sp. nov. and $P$. filamentus sp. nov., gas vacuolate polar marine bacteria of the Cytophaga-Flavobacterium-Bacteroides group and reclassification of 'Flectobacillus glomeratus' as Polaribacter glomeratus comb. nov. Int $J$ Syst Bacteriol 48, 223-235.

Graham, P. H., Sadowsky, M. J., Keyser, H. H. \& 8 other authors (1991). Proposed minimal standards for the description of new genera and species of root- and stem-nodulating bacteria. Int $J$ Syst Bacteriol 41, 582-587.

Grimont, P. A. D., Popoff, M. Y., Grimont, F., Coynault, C. \& Lemelin, M. (1980). Reproducibility and correlation study of three deoxyribonucleic acid hybridization procedures. Curr Microbiol 4, 325-330.

Hansen, G. H., Bergh, Ø., Michaelsen, J. \& Knappskog, D. (1992). Flexibacter ovolyticus sp. nov., a pathogen of eggs and larvae of Atlantic halibut, Hippoglossus hippoglossus L. Int J Syst Bacteriol 42, 451-458.

Hanzawa, N., Kanai, S., Katsuta, A., Nakagawa, Y. \& Yamasato, K. (1995). 16S rDNA-based phylogenetic analysis of marine flavobacteria. $J$ Mar Biotechnol 3, 111-114.

Harrington, C. S. \& On, S. L. W. (1999). Extensive 16S rRNA gene sequence diversity in Campylobacter hyointestinalis strains: taxonomic and applied implications. Int $J$ Syst Bacteriol 49, 1171-1175.

Harrison, F. C. (1929). The discolouration of halibut. Can J Res 1, 214-239.
Hendrickson, J. M. \& Hilbert, K. F. (1932). A new and serious septicemic disease of young ducks with the description of the causative organism, Pfeifferella anatipestifer. Cornell Vet 22, 239-252.

Hildebrand, D. C. (1971). Pectate and pectine gels for differentiation of Pseudomonas sp. and other bacterial pathogens. Phytopathology 61, 1430-1436.

Hirsch, P., Ludwig, W., Hethke, C., Sittig, M., Hoffmann, B. \& Gallikowski, C. A. (1998). Hymenobacter roseosalivarius gen. nov., sp. nov. from continental Antarctic soils and sandstone: bacteria of the Cytophaga/Flavobacterium/Bacteroides line of phylogenetic descent. Syst Appl Microbiol 21, 374-383.

Holdeman, L. V., Cato, E. P. \& Moore, W. E. C. (1977). Anaerobe Laboratory Manual, 4th edn. Blacksburg: Virginia Polytechnic Institute and State University Anaerobe Laboratory.

Holdeman, L. V., Kelley, R. W. \& Moore, W. E. C. (1984). Family I. Bacteroidaceae Pribram 1933, 10 ${ }^{\mathrm{AL}}$. In Bergey's Manual of Systematic Bacteriology, vol. 1, pp. 602-662. Edited by N. R. Krieg \& J. G. Holt. Baltimore, MD: Williams \& Wilkins.

Holmes, B. (1992). The genera Flavobacterium, Sphingobacterium and Weeksella. In The Prokaryotes, 2nd edn, vol. 4, pp. 3620-3630. Edited by A. Balows, H. G. Trüper, M. Dworkin, W. Harder \& K.-H. Schleifer. Berlin: Springer.

Holmes, B. (1997). International Committee on Systematic Bacteriology Subcommittee on the taxonomy of Flavobacterium and Cytophaga-like bacteria, minutes of the meetings, 4 and 6 July 1994, Prague, Czech Republic. Int J Syst Bacteriol 47, 593-594.

Holmes, B. \& Owen, R. J. (1982). Flavobacterium breve sp. nov., nom. rev. Int J Syst Bacteriol 32, 233-234.

Holmes, B., Snell, J. J. S. \& Lapage, S. P. (1977). Revised description, from clinical isolates, of Flavobacterium odoratum Stutzer and Kwaschnina 1929, and designation of the neotype strain. Int J Syst Bacteriol 27, 330-336.

Holmes, B., Snell, J. J. S. \& Lapage, S. P. (1978). Revised description, from clinical strains, of Flavobacterium breve (Lustig) Bergey et al. 1923 and proposal of the neotype strain. Int J Syst Bacteriol 28, 201-208.

Holmes, B., Owen, R. J. \& McMeekin, T. A. (1984a). Genus Flavobacterium Bergey, Harrison, Breed, Hammer and Huntoon 1923, $97^{\mathrm{AL}}$. In Bergey's Manual of Systematic Bacteriology, vol. 1, pp. 353-361. Edited by N. R. Krieg \& J. G. Holt. Baltimore: Williams \& Wilkins.

Holmes, B., Owen, R. J., Steigerwalt, A. G. \& Brenner, D. J. (1984b). Flavobacterium gleum, a new species found in human clinical specimens. Int J Syst Bacteriol 34, 21-25.

Holmes, B., Steigerwalt, A. G., Weaver, R. E. \& Brenner, D. J. (1986a). Weeksella virosa gen. nov., sp. nov. (formerly group IIf), found in human clinical specimens. Syst Appl Microbiol 8, 185-190.

Holmes, B., Steigerwalt, A. G., Weaver, R. E. \& Brenner, D. J. (1986b). Weeksella zoohelcum sp. nov. (formerly group IIj), from human clinical specimens. Syst Appl Microbiol 8, 191-196.

Holt, S. C. \& Kinder, S. A. (1989). Genus Capnocytophaga Leadbetter, Holt and Socransky 1982. In Bergey's Manual of Systematic Bacteriology, vol. 3, pp. 2050-2058. Edited by J. T. Staley, M. P. Bryant, N. Pfennig \& J. G. Holt. Baltimore: Williams \& Wilkins.

Hugo, C. J. (1997). A taxonomic study of the genus Chryseobacterium from food and environmental sources. $\mathrm{PhD}$ thesis, University of the Orange Free State

Hugo, C. J., Jooste, P. J., Segers, P., Vancanneyt, M. \& Kersters, K. (1999). A polyphasic taxonomic study of Chryseobacterium strains isolated from dairy sources. Syst Appl Microbiol 22, 586-595.

Humphry, D. R., George, A., Black, G. W. \& Cummings, S. P. (2001). Flavobacterium frigidarium sp. nov., an aerobic, psychrophilic, xylanolytic and laminarinolytic bacterium from Antarctica. Int J Syst Evol Microbiol 51, 1235-1243.

Hurst, G. D. D., Hammarton, T. C., Bandi, C., Majerus, T. M. O., Bertrand, D. \& Majerus, M. E. N. (1997). The diversity of inherited parasites of insects: the male-killing agent of the ladybird beetle Coleomegilla maculata is a member of the Flavobacteria. Genet Res Camb 70, 1-6.

Hurst, G. D. D., Bandi, C., Sacchi, L., Cochrane, A. G., Bertrand, D., 
Karaca, I. \& Majerus, M. E. N. (1999). Adonia variegata (Coleoptera: Coccinellidae) bears maternally inherited Flavobacteria that kill males only. Parasitology 118, 125-134.

Inoue, K. \& Komagata, K. (1976). Taxonomic study on obligately psychrophilic bacteria isolated from Antarctica. J Gen Appl Microbiol 22, 165-176.

International Committee on Systematic Bacteriology Subcommittee on the taxonomy of Mollicutes (1995). Revised minimum standards for description of new species of the class Mollicutes (division Tenericutes). Int J Syst Bacteriol 45, 605-612.

International Journal of Systematic and Evolutionary Microbiology (2001). Notification that new names and new combinations have appeared in volume 51, part 3, of the IJSEM. Int J Syst Evol Microbiol 51,1231-1233.

Ivanova, E. P., Nedashkovskaya, O. I., Chun, J., Lysenko, A. M., Frolova, G. M., Svetashev, V. I., Vysotskii, M. V., Mikhailov, V. V., Huq, A. \& Colwell, R. R. (2001). Arenibacter gen. nov., new genus of the family Flavobacteriaceae and description of a new species, Arenibacter latericius sp. nov. Int J Syst Evol Microbiol 51, 1987-1995.

Johansen, J. E., Nielsen, P. \& Sjøholm, C. (1999). Description of Cellulophaga baltica gen. nov., sp. nov. and Cellulophaga fucicola gen. nov., sp. nov. and reclassification of [Cytophaga] lytica to Cellulophaga lytica gen. nov., comb. nov. Int J Syst Bacteriol 49, 1231-1240.

Johnson, J. L. \& Chilton, W. S. (1966). Galactosamine glycan of Chondrococcus columnaris. Science 152, 1247-1248.

Jooste, P. J. (1985). The taxonomy and significance of FlavobacteriumCytophaga strains from dairy sources. $\mathrm{PhD}$ thesis, University of the Orange Free State.

Kaiser, P. (1961). Etude de l'activité pectinolytique du sol et d'autres substrats naturels. Thèse de l'Université de Paris.

Kimura, M. (1980). A simple method for estimating evolutionary rates of base substitutions through comparative studies of nucleotide sequences. J Mol Evol 16, 111-120.

King, E. O. (1959). Studies on a group of previously unclassified bacteria associated with meningitis in infants. Am J Clin Pathol 31, 241-247.

Kondo, R., Imai, I., Fukami, K., Minami, A. \& Hiroishi, S. (1999). Phylogenetic analysis of algicidal bacteria (family Flavobacteriaceae) and selective detection by PCR using a specific primer set. Fish Sci $\mathbf{6 5}$, 432-435.

Koski, P., Hirvelä-Koski, V. \& Bernardet, J.-F. (1993). Flexibacter columnaris infection in Arctic char (Salvelinus alpinus L.); first isolation in Finland. Bull Eur Assoc Fish Pathol 13, 66-69.

Krasil'nikov, N. A. (1949). Guide to the Bacteria and Actinomycetes. Moscow: Akad Nauk SSSR.

Labeda, D. P. (1997). International Committee on Systematic Bacteriology VIIth International Congress of Microbiology and Applied Bacteriology, minutes of the meetings, 17, 18 and 22 August 1996, Jerusalem, Israel. Int J Syst Bacteriol 47, 597-600.

Labeda, D. P. (2000). International Committee on Systematic Bacteriology IXth International (IUMS) Congress of Bacteriology and Applied Microbiology, minutes of the meetings, 14 and 17 August 1999, Sydney, Australia. Int J Syst Evol Microbiol 50, 2245-2247.

Lapage, S. P., Sneath, P. H. A., Lessel, E. F., Skerman, V. B. D. Seeliger, H. P. R. \& Clark, W. A. (editors) (1992). International Code of Nomenclature of Bacteria (1990 Revision). Bacteriological Code. Washington, DC: American Society for Microbiology.

Larkin, J. M. \& Borrall, R. (1984). Family I. Spirosomaceae Larkin and Borrall $1978,595^{\mathrm{AL}}$. In Bergey's Manual of Systematic Bacteriology, vol. 1, pp. 125-132. Edited by N. R. Krieg \& J. G. Holt. Baltimore: Williams \& Wilkins.

Leadbetter, E. R. (1974). Order II. Cytophagales Nomen novum. In Bergey's Manual of Determinative Bacteriology, 8th edn, pp. 99-122. Edited by R. E. Buchanan \& N. E. Gibbons. Baltimore: Williams \& Wilkins.

Leadbetter, E. R., Holt, S. C. \& Socransky, S. S. (1979). Capnocytophaga: new genus of Gram-negative gliding bacteria. I. General characteristics, taxonomic considerations and significance. Arch Microbiol 122, 9-16.

Lewin, R. A. (1969). A classification of flexibacteria. J Gen Microbiol 58, 189-206.

Lewin, R. A. \& Lounsbery, D. M. (1969). Isolation, cultivation and characterization of flexibacteria. J Gen Microbiol 58, 145-170.

London, J., Celesk, R. A., Kagermeier, A. \& Johnson, J. L. (1985). Emended description of Capnocytophaga gingivalis. Int J Syst Bacteriol 35, 369-370.

Lustig, A. (1890). Diagnostica dei Batteri delle Acque con una Guida alle Ricerche Batteriologiche e Microscopiche. Torino: Rosenberg \& Sellier.

MacAdoo, T. O. (1993). Nomenclatural literacy. In Handbook of New Bacterial Systematics, pp. 339-358. Edited by M. Goodfellow \& A. G. O'Donnell. New York: Academic Press

Macián, M. C., Pujalte, M. J., Márquez, M. C., Ludwig, W., Ventosa, A., Garay, E. \& Schleifer, K. H. (2002). Gelidibacter mesophilus sp. nov., a new marine bacterium in the family Flavobacteriaceae. Int $J$ Syst Evol Microbiol 52 (in press).

Maeda, T., Murakami, M., Ohsugi, S., Furushita, M., Mitsutani, A. \& Shiba, T. (1998). Perspectives of the development of 16S rDNA probe specific for algicidal and/or algal-lytic gliding bacteria. Fish Sci 64, 861-865

Maidak, B. L., Cole, J. R., Parker, C. T., Jr \& 11 other authors (1999). A new version of the RDP (Ribosomal Database Project). Nucleic Acids Res 27, 171-173.

Manz, W., Amann, R., Ludwig, W., Vancanneyt, M. \& Schleifer, K.-H. (1996). Application of a suite of 16S rRNA-specific oligonucleotide probes designed to investigate bacteria of the phylum cytophagaflavobacter-bacteroides in the natural environment. Microbiology $\mathbf{1 4 2}$, $1097-1106$

McCammon, S. A. \& Bowman, J. P. (2000). Taxonomy of Antarctic Flavobacterium species: description of Flavobacterium gillisiae sp. nov., Flavobacterium tegetincola sp. nov., and Flavobacterium xanthum sp. nov., nom. rev. and reclassification of [Flavobacterium] salegens as Salegentibacter salegens gen. nov., comb. nov. Int J Syst Evol Microbiol 50, 1055-1063.

McCammon, S. A., Innes, B. H., Bowman, J. P., Franzmann, P. D., Dobson, S. J., Holloway, P. E., Skerratt, J. H., Nichols, P. D. \& Rankin, L. M. (1998). Flavobacterium hibernum sp. nov., a lactoseutilizing bacterium from a freswater Antarctic lake. Int J Syst Bacteriol 48, 1405-1412.

McGrath, C. F., Moss, C. W. \& Burchard, R. P. (1990). Effect of temperature shifts on gliding motility, adhesion, and fatty acid composition of Cytophaga sp. strain U67. J Bacteriol 172, 1978-1982.

McGuire, A. J., Franzmann, P. D. \& McMeekin, T. A. (1987). Flectobacillus glomeratus sp. nov., a curved, nonmotile, pigmented bacterium isolated from Antartic marine environments. Syst Appl Microbiol 9, 265-272.

Moore, W. E. C., Cato, E. P. \& Moore, L. V. H. (1985). Index of the bacterial and yeast nomenclatural changes published in the International Journal of Systematic Bacteriology since the 1980 approved lists of bacterial names (1 January 1980 to 1 January 1985). Int J Syst Bacteriol 35, 382-407.

Mudarris, M., Austin, B., Segers, P., Vancanneyt, M., Hoste, B. \& Bernardet, J.-F. (1994). Flavobacterium scophthalmum sp. nov., a pathogen of turbot (Scophthalmus maximus L.). Int J Syst Bacteriol 44, 447-453.

Müller, K.-D., Schmid, E. N. \& Michel, R. (1999). Intracellular bacteria of Acanthamoebae resembling Legionella spp. turned out to be Cytophaga sp. Zentbl Bakteriol 289, 389-397.

Murray, R. G. E., Brenner, D. J., Colwell, R. R., De Vos, P., Goodfellow, M., Grimont, P. A. D., Pfennig, N., Stackebrandt, E. \& Zavarzin, G. A. (1990). Report of the ad hoc committee on approaches to taxonomy within the Proteobacteria. Int J Syst Bacteriol 40, 213-215.

Murray, R. G. E. \& Stackebrandt, E. (1995). Taxonomic note: implementation of the provisional status Candidatus for incompletely described procaryotes. Int J Syst Bacteriol 45, 186-187. 
Nakagawa, Y. \& Yamasato, K. (1993). Phylogenetic diversity of the genus Cytophaga revealed by $16 \mathrm{~S}$ rRNA sequencing and menaquinone analysis. J Gen Microbiol 139, 1155-1161.

Nakagawa, Y. \& Yamasato, K. (1996). Emendation of the genus Cytophaga and transfer of Cytophaga agarovorans and Cytophaga salmonicolor to Marinilabilia gen. nov.: phylogenetic analysis of the Flavobacterium-Cytophaga complex. Int J Syst Bacteriol 46, 599-603.

Nakagawa, Y., Suzuki, M. \& Hatano, K. (2001). Phylogenetic diversity of Cytophaga-like strains isolated from the sub-tropical zone of Japan. IFO Res Commun 20, 61-71.

Nei, M. (1987). Molecular Evolutionary Genetics. New York: Columbia University Press.

Ordal, E. J. \& Rucker, R. R. (1944). Pathogenic myxobacteria. Proc Soc Exp Biol Med 56, 15-18.

Oren, A., Ventosa, A. \& Grant, W. D. (1997). Proposed minimal standards for description of new taxa in the order Halobacteriales. Int J Syst Bacteriol 47, 233-238.

Ostland, V. E., Lumsden, J. S., MacPhee, D. D. \& Ferguson, H. W. (1994). Characteristics of Flavobacterium branchiophilum, the cause of salmonid bacterial gill disease in Ontario. J Aquat Anim Health 6, 13-26.

Owen, R. J. \& Pitcher, D. (1985). Current methods for estimating DNA base composition and levels of DNA-DNA hybridization. In Chemical Methods in Bacterial Systematics, pp. 67-93. Edited by M. Goodfellow \& D. E. Minnikin. London: Academic Press.

Oyaizu, H. \& Komagata, K. (1981). Chemotaxonomic and phenotypic characterization of the strains of species in the Flavobacterium-Cytophaga complex. J Gen Appl Microbiol 27, 57-107.

Paster, B. J., Dewhirst, F. E., Olsen, I. \& Fraser, G. J. (1994). Phylogeny of Bacteroides, Prevotella, and Porphyromonas spp. and related bacteria. J Bacteriol 176, 725-732.

Popoff, M. \& Coynault, C. (1980). Use of DEAE-cellulose filters in the S1 nuclease method for bacterial deoxyribonucleic acid hybridization. Ann Microbiol Inst Pasteur 131A, 151-155.

Potin, P., Sanséau, A., Le Gall, Y., Rochas, C. \& Kloareg, B. (1991). Purification and characterization of a new $\kappa$-carrageenase from a marine Cytophaga-like bacterium. Eur J Biochem 201, 241-247.

Prévot, A. R. (1961). Traité de Systématique Bactérienne. Paris: Dunod. Raj, H. D. \& Maloy, S. R. (1990). Family Spirosomaceae: Gramnegative ring-forming aerobic bacteria. Crit Rev Microbiol 17, 329-364. Reichenbach, H. (1989). Order I. Cytophagales Leadbetter 1974. In Bergey's Manual of Systematic Bacteriology, vol. 3, pp. 2011-2013. Edited by J. T. Staley, M. P. Bryant, N. Pfennig \& J. G. Holt. Baltimore: Williams \& Wilkins.

Reichenbach, H. (1992a). The Order Cytophagales. In The Prokaryotes, 2nd edn, vol. 4, pp. 3631-3687. Edited by A. Balows, H. G. Trüper, M. Dworkin, W. Harder \& K.-H. Schleifer. Berlin: Springer.

Reichenbach, H. (1992b). Flavobacteriaceae fam. nov. In Validation of the Publication of New Names and New Combinations Previously Effectively Published Outside the IJSB, List no. 41. Int J Syst Bacteriol 42, 327-329.

Reichenbach, H. \& Dworkin, M. (1981). Introduction to the gliding bacteria. In The Prokaryotes, vol. 1, pp. 315-327. Edited by M. P. Starr, H. Stolp, H. G. Trüper, A. Balows \& H. G. Schlegel. Berlin: Springer Richard, C. \& Kiredjian, M. (1995). Laboratory Methods for the Identification of Strictly Aerobic Gram-negative Bacilli. Paris: Institut Pasteur.

Saitou, N. \& Nei, M. (1987). The neighbor-joining method: a new method for reconstructing phylogenetic trees. Mol Biol Evol 4, 406-425.

Segers, P., Mannheim, W., Vancanneyt, M., De Brandt, K., Hinz, K.-H., Kersters, K. \& Vandamme, P. (1993a). Riemerella anatipestifer gen. nov., the causative agent of septicemia anserum exsudativa, and its phylogenetic affiliation within the Flavobacterium-Cytophaga rRNA homology group. Int J Syst Bacteriol 43, 768-776.

Segers, P., Vandamme, P., Steyn, P. L., Mannheim, W., Willekens, H., Bauwens, M., De Ley, J. \& Kersters, K. (1993b). Phylogenetic studies of Flavobacterium and related organisms by DNA-rRNA hybridizations. In Advances in the Taxonomy and Significance of Flavobacterium, Cytophaga and Related Bacteria, pp. 129-136. Edited by P. J. Jooste. Bloemfontein, South Africa: University of the Orange Free State Press.

Skerman, V. B. D., McGowan, V. \& Sneath, P. H. A. (1980). Approved lists of bacterial names. Int J Syst Bacteriol 30, 225-420.

Sly, L. I., Taghavi, M. \& Fegan, M. (1998). Phylogenetic heterogeneity within the genus Herpetosiphon: transfer of the marine species Herpetosiphon cohaerens, Herpetosiphon nigricans and Herpetosiphon persicus to the genus Lewinella gen. nov. in the Flexibacter-Bacteroides-Cytophaga phylum. Int J Syst Bacteriol 48, 731-737.

Smibert, R. M. \& Krieg, N. R. (1994). Phenotypic characterization. In Methods for General and Molecular Bacteriology, pp. 607-654. Edited by P. Gerhardt, R. G. E. Murray, W. A. Wood \& N. R. Krieg. Washington, DC: American Society for Microbiology.

Sneath, P. H. A. \& Sokal, R. R. (1973). Numerical Taxonomy: the Principles and Practice of Numerical Classification. San Francisco: Freeman.

Socransky, S. S., Holt, S. C., Leadbetter, E. R., Tanner, A. C. R., Savitt, E. \& Hammond, B. F. (1979). Capnocytophaga: new genus of Gram-negative gliding bacteria. III. Physiological characterization. Arch Microbiol 122, 29-33.

Stackebrandt, E. \& Goebel, B. M. (1994). Taxonomic note: a place for DNA-DNA reassociation and 16S rRNA sequence analysis in the present species definition in bacteriology. Int $J$ Syst Bacteriol 44, 846-849.

Stanier, R. Y. (1947). Studies on non-fruiting myxobacteria. I. Cytophaga johnsonae $\mathrm{n}$. sp., a chitin-decomposing myxobacterium. $J$ Bacteriol 53, 297-315.

Stanier, R. Y. (1957). Order VIII. Myxobacterales Jahn 1915. In Bergey's Manual of Determinative Bacteriology, 7th edn, pp. 854-891. Edited by R. S. Breed, E. G. D. Murray \& N. R. Smith. Baltimore: Williams \& Wilkins.

Steyn, P. L., Segers, P., Vancanneyt, M., Sandra, P., Kersters, K. \& Joubert, J. J. (1998). Classification of heparinolytic bacteria into a new genus, Pedobacter, comprising four species: Pedobacter heparinus comb. nov., Pedobacter piscium comb. nov., Pedobacter africanus sp. nov. and Pedobacter saltans sp. nov. Proposal of the family Sphingobacteriaceae fam. nov. Int J Syst Bacteriol 48, 165-177.

Strohl, W. R. \& Tait, L. R. (1978). Cytophaga aquatilis sp. nov., a facultative anaerobe isolated from the gills of freshwater fish. Int J Syst Bacteriol 28, 293-303.

Stutzer, M. \& Kwaschnina, A. (1929). Aussaaten aus den Fäzes des Menschen gelbe Kolonien bildende Bakterien (Gattung Flavobacterium u.a.). Zentbl Bakteriol Parasitenkd Infektionskr Hyg Abt I Orig 113, 219-225.

Suzuki, K., Goodfellow, M. \& O’Donnell, A. G. (1993). Cell envelopes and classification. In Handbook of New Bacterial Systematics, pp. 195-250. Edited by M. Goodfellow \& A. G. O'Donnell. New York: Academic Press.

Suzuki, M., Nakagawa, Y., Harayama, S. \& Yamamoto, S. (2001). Phylogenetic analysis and taxonomic study of marine Cytophaga-like bacteria: proposal for Tenacibaculum gen. nov. with Tenacibaculum maritimum comb. nov. and Tenacibaculum ovolyticum comb. nov., and description of Tenacibaculum mesophilum sp. nov. and Tenacibaculum amylolyticum sp. nov. Int J Syst Evol Microbiol 51, 1639-1652.

Thompson, J. D., Higgins, D. G. \& Gibson, T. J. (1994). CLUSTAL w: improving the sensitivity of progressive multiple sequence alignment through sequence weighting, positions-specific gap penalties and weight matrix choice. Nucleic Acids Res 22, 4673-4680.

Tindall, B. J. (1999). Proposal to change the Rule governing the designation of type strains deposited under culture collection numbers allocated for patent purposes. Int J Syst Bacteriol 49, 1317-1319.

Topley, W. W. C. \& Wilson, G. S. (1929). The Principles of Bacteriology and Immunity. London: E. Arnold.

Triyanto \& Wakabayashi, H. (1999). Genotypic diversity of strains of Flavobacterium columnare from diseased fishes. Fish Pathol 34 65-71.

Trüper, H. G. (1996). Help! Latin! How to avoid the most common 
mistakes while giving Latin names to newly discovered prokaryotes Microbiol SEM 12, 473-475.

Ursing, J. \& Bruun, B. (1987). Genetic heterogeneity of Flavobacterium meningosepticum demonstrated by DNA-DNA hybridization. Acta Path Microbiol Immunol Scand Sect B 95, 33-39.

Ursing, J. \& Bruun, B. (1991). Genetic heterogeneity of Flavobacterium group IIb and Flavobacterium breve demonstrated by DNA-DNA hybridization. Acta Path Microbiol Immunol Scand Sect B 99, 780-786.

Ursing, J. B., Lior, H. \& Owen, R. J. (1994). Proposal of minimal standards for describing new species of the family Campylobacteraceae. Int J Syst Bacteriol 44, 842-845.

Vancanneyt, M., Segers, P., Torck, U., Hoste, B., Bernardet, J.-F., Vandamme, P. \& Kersters, K. (1996). Reclassification of Flavobacterium odoratum (Stutzer 1929) strains to a new genus, Myroides, as Myroides odoratus comb. nov. and Myroides odoratimimus sp. nov. Int J Syst Bacteriol 46, 926-932.

Vancanneyt, M., Vandamme, P., Segers, P., Torck, U., Coopman, R., Kersters, K. \& Hinz, K.-H. (1999). Riemerella columbina sp. nov., a bacterium associated with respiratory disease in pigeons. Int J Syst Bacteriol 49, 289-295.

Vandamme, P., Bernardet, J.-F., Segers, P., Kersters, K. \& Holmes, B. (1994a). New perspectives in the classification of the flavobacteria: description of Chryseobacterium gen. nov., Bergeyella gen. nov., and Empedobacter nom. rev. Int J Syst Bacteriol 44, 827-831.

Vandamme, P., Segers, P., Vancanneyt, M. \& 11 other authors (1994b). Ornithobacterium rhinotracheale gen. nov., sp. nov., isolated from the avian respiratory tract. Int $J$ Syst Bacteriol 44, 24-37.

Vandamme, P., Pot, B., Gillis, M., De Vos, P., Kersters, K. \& Swings, J. (1996a). Polyphasic taxonomy, a consensus approach to bacterial systematics. Microbiol Rev 60, 407-438.

Vandamme, P., Vancanneyt, M., van Belkum, A., Segers, P., Quint, W. G. V., Kersters, K., Paster, B. J. \& Dewhirst, F. E. (1996b). Polyphasic analysis of strains of the genus Capnocytophaga and Centers for Disease Control group DF-3. Int J Syst Bacteriol 46, 782-791.

Vandamme, P., Vancanneyt, M., Segers, P., Ryll, M., Köhler, B., Ludwig, W. \& Hinz, K.-H. (1999). Coenonia anatina gen. nov., sp. nov., a novel bacterium associated with respiratory disease in ducks and geese. Int J Syst Bacteriol 49, 867-874.

van der Meulen, H. J., Harder, W. \& Veldkamp, H. (1974). Isolation and characterization of Cytophaga flevensis sp. nov., a new agarolytic flexibacterium. Antonie Leeuwenhoek J Microbiol 40, 329-346.

Vauterin, L., Yang, P., Hoste, B., Vancanneyt, M., Civerolo, E. L., Swings, J. \& Kersters, K. (1991). Differentiation of Xanthomonas campestris pv. citri strains by sodium dodecylsulfate-polyacrylamide gel electrophoresis of proteins, fatty acid analysis, and DNA-DNA hybridization. Int J Syst Bacteriol 41, 535-542.

Vauterin, L., Swings, J. \& Kersters, K. (1993). Protein electrophoresis and classification. In Handbook of New Bacterial Systematics, pp. 251-281. Edited by M. Goodfellow \& A. G. O'Donnell. New York, NY: Academic Press.

Vincent Lévy-Frébault, V. \& Portaels, F. (1992). Proposed minimal standards for the genus Mycobacterium and for description of new slowly growing Mycobacterium species. Int J Syst Bacteriol 42, 315-323.
Wakabayashi, H., Hikida, M. \& Masumura, K. (1986). Flexibacter maritimus sp. nov., a pathogen of marine fishes. Int J Syst Bacteriol 36, 396-398.

Wakabayashi, H., Huh, G. J. \& Kimura, N. (1989). Flavobacterium branchiophila sp. nov., a causative agent of bacterial gill disease of freshwater fishes. Int J Syst Bacteriol 39, 213-216.

Wayne, L. G., Brenner, D. J., Colwell, R. R. \& 9 other authors (1987). International Committee on Systematic Bacteriology. Report of the ad hoc committee on reconciliation of approaches to bacterial systematics. Int J Syst Bacteriol 37, 463-464.

Weeks, O. B. (1974). Genus Flavobacterium Bergey et al. 1923. In Bergey's Manual of Determinative Bacteriology, 8th edn, pp. 357-364. Edited by R. E. Buchanan \& N. E. Gibbons. Baltimore: Williams \& Wilkins.

Weeks, O. B. (1981). Preliminary studies of the pigments of Flavobacterium breve NCTC 11099 and Flavobacterium odoratum NCTC 11036. In The Flavobacterium-Cytophaga Group, pp. 108-114. Edited by H. Reichenbach \& O. B. Weeks. Weinheim: Gesellschaft für Biotechnologische Forschung.

West, P. A. \& Colwell, R. R. (1984). Identification and classification of the Vibrionaceae - an overview. In Vibrios in the Environment, pp. 285-363. Edited by R. R. Colwell. New York: Wiley.

Woese, C. R., Stackebrandt, E., Macke, T. J. \& Fox, G. E. (1985). A phylogenetic definition of the major eubacterial taxa. Syst Appl Microbiol 6, 143-151.

Woese, C. R., Maloy, S., Mandelco, L. \& Raj, H. D. (1990a). Phylogenetic placement of the Spirosomaceae. Syst Appl Microbiol 13, 19-23. Woese, C. R., Yang, D., Mandelco, L. \& Stetter, K. O. (1990b). The Flexibacter-Flavobacter connection. Syst Appl Microbiol 13, 161-165. Yabuuchi, E., Kaneko, T., Yano, I., Moss, C. W. \& Miyoshi, N. (1983). Sphingobacterium gen. nov., Sphingobacterium spiritivorum comb. nov., Sphingobacterium multivorum comb. nov., Sphingobacterium mizutae sp. nov., and Flavobacterium indologenes sp. nov.: glucose-nonfermenting gram-negative rods in CDC groups IIk-2 and IIb. Int J Syst Bacteriol 33, 580-598.

Yabuuchi, E., Hashimoto, Y., Ezaki, T., Ido, Y. \& Takeuchi, N. (1990). Genotypic and phenotypic differentiation of Flavobacterium indologenes Yabuuchi et al. 1983 from Flavobacterium gleum Holmes et al. 1984. Microbiol Immunol 34, 73-76.

Yamaguchi, S. \& Yokoe, M. (2000). A novel protein-deamidating enzyme from Chryseobacterium proteolyticum sp. nov., a newly isolated bacterium from soil. Appl Environ Microbiol 66, 3337-3343.

Yamamoto, S. \& Harayama, S. (1996). Phylogenetic analysis of Acinetobacter strains based on the nucleotide sequences of $\operatorname{gyr} B$ genes and on the amino acids sequences of their products. Int $J$ Syst Bacteriol 46, 506-511.

Yamamoto, T., Kajiura, S., Hirai, Y. \& Watanabe, T. (1994). Capnocytophaga haemolytica sp. nov. and Capnocytophaga granulosa sp. nov., from human dental plaque. Int J Syst Bacteriol 44, 324-329.

ZoBell, C. E. \& Upham, H. C. (1944). A list of marine bacteria including descriptions of sixty new species. Bull Scripps Inst Oceanogr Univ Calif (Techn Series) 5, 239-292. 